\title{
COURTS: IN AND OUT OF SIGHT, SITE, AND CITE
}

The Norman Shachoy Lecture

\author{
JUDITH RESNIK†
}

\section{Setting the Scene (Or its Absence): The Vanishing Trial}

$\mathrm{O}$ $\mathrm{N}$ several occasions during the fall of 2007 , groups gathered to address "judicial transparency" - the question that animates this symposium. In addition to conferences convened by RAND's Institute for Civil Justice and UCLA Law School in Los Angeles, ${ }^{1}$ by Villanova University outside of Philadelphia, and at Birkbeck College of the University of London, ${ }^{2}$ federal legislators turned their attention to what proponents called "sunshine." Two bills-one aimed at expanding judicial authority and the other at constraining it-were introduced in Congress. One proposal (the "Sunshine in the Courtroom Act of 2007") would authorize federal appellate and trial judges to permit the photographing and the

† Arthur Liman Professor of Law, Yale Law School. (c) All rights reserved. This article was first presented as the Norman J. Shachoy Lecture, the keynote address at the Villanova University School of Law Symposium: The Future of Judicial Transparency, held at Villanova Law School on February 2, 2008. My thanks to the participants from whom I learned a great deal, to the convenors Steven L. Chanenson, Michael W. Carroll, and Penelope Pether; to Yale law librarians Camilla Tubbs and Michael Widener for their insightful guidance and advice; to Linda Mulcahy, Piyel Haldar, Marc Galanter, Nancy Marder and the other participants at the workshop at Birkbeck College; to Kim Scheppelle, Olivier Dutheillet; to Allison Tait, Stella Burch, Chavi Kenney Nana, Vasudha Talla, Laurie Ball, Joseph Frueh, Kate Desormeau, Natalie Ram, Julia Schiesel, Phu Nguyen, Dane Lund, Naima Farrell, Laura Heiman, and Hannah Hubler whose research has been so thoughtful and thorough, and to Susan Monsen, Cassie Klatka and Lucinda Currell for technical assistance.

This Lecture overlaps with-and builds on-a book underway as well as on essays written with Dennis E. Curtis, whose thoughts infuse this commentary. See Judith Resnik \& Dennis E. Curtis, From 'Rites' to 'Rights' of Audience: The Utilities and Contingencies of the Public's Role in Court-Based Processes, in REPRESENTATIONS OF Justice (Antoine Masson \& Kevin O'Connor eds., 2007); Judith Resnik \& Dennis E. Curtis, Representing Justice: From Renaissance Iconography to Twenty-First-Century Courthouses, 151 Proc. AM. PhIL. Soc'y 139 (2007) [hereinafter Resnik \& Curtis, Representing Justice]; see also Judith Resnik, The Marx Lecture, The Places of Power of the State: From Renaissance Town Halls to Guantánamo Bay, 77 U. Cin. L. Rev. (forthcoming 2009); Judith Resnik, Whither and Whether Adjudication?, 86 B.U. L. Rev. 1101 (2006); Judith Resnik, Uncovering, Disclosing, and Discovering How the Public Dimensions of Court-Based Processes Are at Risk, 81 CHI.-Kent L. Rev. 521 (2006).

1. RAND \& UCLA Sch. of Law Conference, Transparency in the Civil Justice System (2007); those papers will be part of a forthcoming book. See RAND, Events, Transparency in the Civil Justice System, http://www.rand.org/events/2007/11/ 02 (last visited June 28, 2008). See also Henry Weinstein, Prying into Judicial Secrecy, L.A. Times, Nov. 3, 2007, at B3.

2. Birkbeck College, Univ. of London Symposium, Adjudicatory Practices in Transition: Courts and the Public Sphere (Dec. 11, 2007). 
televising of proceedings under certain circumstances. ${ }^{3}$ Another initiative (the "Sunshine in Litigation Act of 2007") would limit the power of federal judges to permit parties to seal settlements or to promise confidentiality of discovery materials in civil cases. ${ }^{4}$

Why has the topic of judicial transparency garnered this attention? The high visibility end of the litigation docket provides one reason. In the wake of $9 / 11$, both civil and criminal cases have raised issues about access to information, government surveillance, and open decision-making. Citing national security, the United States government has repeatedly argued that it should not have to reveal information to federal judges charged with reviewing the lawfulness of classifications of individuals as "enemy combatants." 5 The federal government has also sought and succeeded in obtaining dismissals—on the basis of "state's secrets" - of cases claiming that persons under its charge have been sent to countries where they have been tortured or abused. ${ }^{6}$

3. See Sunshine in the Courtroom Act of 2007, H.R. 2128, 110th Cong. (2007); Sunshine in the Courtroom Act of 2008, S. 352, 110th Cong. (2008). The House bill, co-sponsored by Representatives Chabot and Delahunt, provides federal appellate and district court judges the discretion to "permit the photographing, electronic recording, broadcasting, or televising to the public of any court proceeding over which that judge presides," unless this would violate the "due process rights of any party." See H.R. $2128 \S 2(\mathrm{~b})(1)(\mathrm{B}) ; \quad \S 2(\mathrm{~b})(2)(\mathrm{A})$ (iii). For federal trials, jurors may not be televised, and witnesses may request that their faces and voices be disguised so that they are unrecognizable to the broadcast audience. See H.R. $2128 \S 2$ (b) (2) (A) (ii); § 2(b) (2) (B). The text of the Senate bill, cosponsored by Senators Grassley, Schumer, Leahy, Specter, Graham, Feingold, Cornyn, Durbin, Craig and Allard, is identical. See S. 352.

4. See Sunshine in Litigation Act of 2007, S. 2449, 110th Cong. (2007). I submitted testimony for the record in that hearing. See The Sunshine in Litigation Act: Does Court Secrecy Undermine Public Health and Safety: Hearing on S. 2449 Before the Subcomm. on Antitrust, Competition Policy and Consumer Rights of the S. Comm. on the Judiciary, 110th Cong. 181-205 (2007) (statement of Judith Resnik, Arthur Liman Professor of Law, Yale Law School). This bill is sponsored by Senator Herbert Kohl of Wisconsin who had proposed related bills in earlier sessions. See, e.g., Sunshine in Litigation Act of 2005, S. 1348, 109th Cong. (2005); Cameras in the Courtroom: Hearing on S. 829 and S. 1768 Before the S. Comm. on the Judiciary, 109th Cong. $331(2005)$.

5. See, e.g., Bismullah v. Gates, 503 F.3d 137, 139-40 (D.C. Cir. 2007), vacated and remanded sub nom. Gates v. Bismullah, 128 S. Ct. 2960 (2008). The D.C. Circuit decision held that in order for the court to discharge its function under the Detainee Treatment Act, the government had to provide the court with the "reasonably available information in the possession of the U.S. Government bearing on the issue of whether the detainee meets the criteria to be designated as an enemy combatant ...."The government then sought expedited review in the United States Supreme Court on the grounds that complying with the lower court's order would constitute an enormous burden-by requiring that a "record" be created for each detainee-and seriously jeopardize national security because such a record would likely include highly sensitive classified material. See Motion for Expedited Consideration of the Petition for Writ of Certiorari at 8-9, Gates v. Bismullah, 128 S. Ct. 2960 (2008) (No. 07-1054).

6. See, e.g., El-Masri v. United States, 479 F.3d 296 (4th Cir. 2007), cert. denied, 128 S. Ct. 373 (2007). These issues are in play worldwide. See, e.g., Privilege for the State, 5731-1971, 2 LSI 198 (1968-72) (Isr.); Law No. 98-567 of July 8, 1998, Journal 
Another reason why many people are focusing on the public nature of court procedures is the growing awareness of a more general phenomenon-the privatization of court-based processes across the docket that becomes apparent through an assessment of trends in aggregate data over time. This point is illustrated by a chart, Civil and Criminal Trial Rates, United States Federal Courts (1976-2000) (fig.1), that maps the rate of trials between 1976 and 2000 in the federal courts of the United States. ${ }^{7}$ Both civil and criminal cases show a downward slope. While minor variations exist, other data demonstrate that in every kind of case the trend line is the same: even as filings have increased, the percentages of cases going to

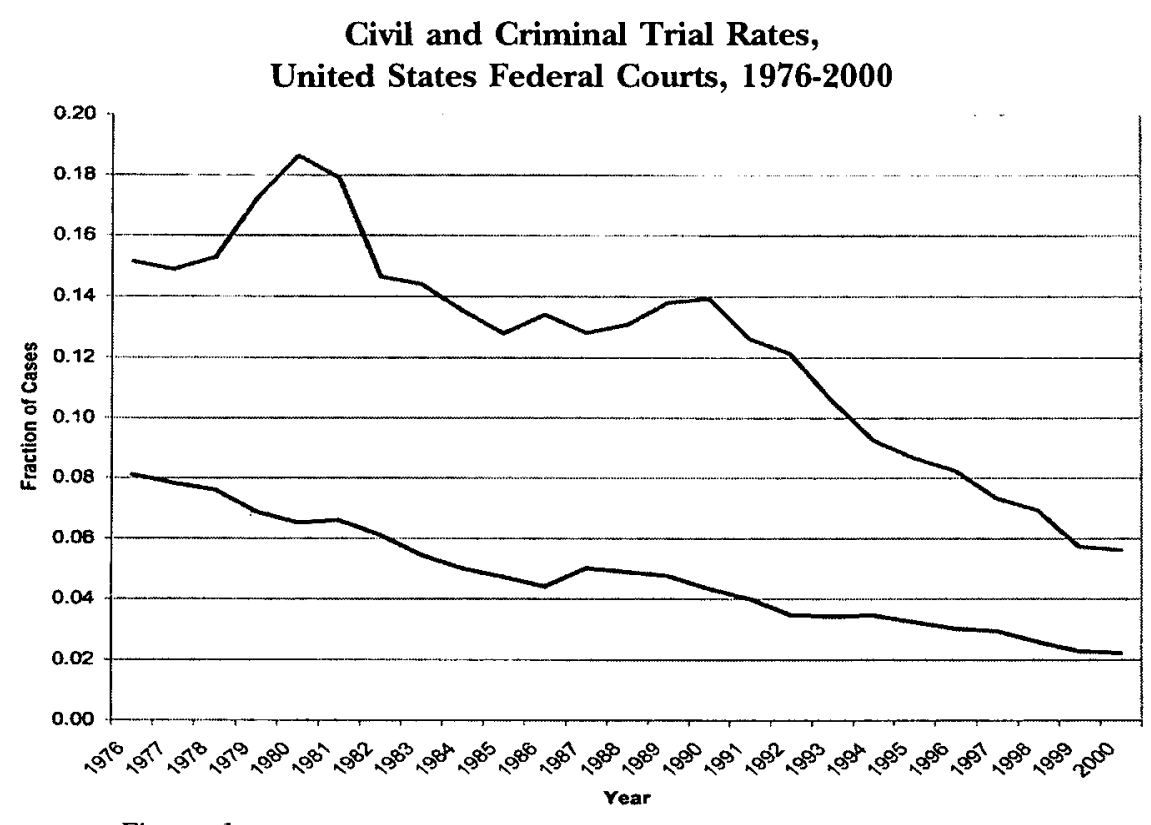

Figure 1.

Officiel de la République Française [J.O.] [Official Gazette of France], July 9, 1998, p.10488; Bundesverfassungsgericht [BVerfG] [Federal Constitutional Court] 1 BvR 385/90 (1999) (F.R.G.); see also Botmeh \& Alami v. United Kingdom, App. No. 15187/03, Eur. Ct. H.R. (June 7, 2007); Ami Kobo, Privileged Evidence and State Security Under the Israeli Law: Are We Doomed To Fail?, 5 Cardozo Pub. L. Pol'y \& ETHICS J. 113 (2007). Descriptions of the handling of materials related to national security are provided by Robert Timothy REAGan, Fed. Judicial CTR., TERrorismRelated Cases: Special Case-Management Challenges (2008) and in Robert Timothy Reagan, Classified Information in Federal Court, 53 VILL. L. Rev. 889 (2008).

7. This figure is provided by and reproduced with the permission of the Honorable Patrick Higginbotham. Judge Higginbotham has served as the Chair of the United States Judicial Conference Committee that reviews the Federal Rules of Civil Procedure and has written many articles about the federal system. He too has voiced his concern about the trend away from trials. See Patrick E. Higginbotham, Judge Robert A. Ainsworth, Jr., Memorial Lecture, Loyola University School of Law: So Why Do We Call Them Trial Courts?, 55 SMU L. Rev. 1405, 1423 (2002). 
trial (and the absolute numbers of trials) have declined. ${ }^{8}$ Information from the states shows a comparable pattern of declining numbers of trials. ${ }^{9}$ The image portrayed in this first chart has become known in the legal community over the last few years as part of what Marc Galanter has named "the Vanishing Trial." ${ }^{0}$ As his data show, the decline in trials has continued. Of one hundred civil cases filed, trials start in fewer than two. ${ }^{11}$

I open my discussion with this chart to outline the three purposes of this Shachoy Lecture. First, although this symposium is dedicated to the question of the "future of transparency," understanding the history of why transparency is associated with courts is essential. Today's rights of public access to courts developed out of Renaissance traditions that put aspects of adjudication before the public eye. Below, I trace the shift from what were once rituals and spectacles of public power to democratic rights of access to open and public courts.

Second, I explain how, during the last few decades, these public processes are being replaced through three principal techniques: reconfiguring the processes within courts, outsourcing some of the activity of courts, and precluding access to courts. As a consequence, much of what was or could have been public becomes private.

But to show change is not necessarily to object to it. The questions raised by the chart mapping the decline in rates of cases going to trial are whether the fact of the "vanishing trial" is a problem and, if so, why. Given that procedural processes are regularly reconfigured, what-aside from tradition-is at stake as trials "vanish"? My third purpose is to provide an answer by outlining a theory of why democracies ought to care about public adjudicatory processes and, therefore, to devise new methods to preserve the public dimensions of dispute resolution.

8. See Marc Galanter, The Vanishing Trial: An Examination of Trials and Related Matters in Federal and State Courts, 1 J. EMPirical Legal Stud. 459 (2004).

9. See id. at 506-13; see also Brian J. Ostrom, Shauna M. Strickland \& Paula L. Hannaford-Agor, Examining Trial Trends in State Courts: 1976-2002, 1 J. EMPIRICAL LEGAL STUd. 755 (2004).

10. In 1962,5802 civil trials took place; forty years later in 2002 , with many more cases filed, 4569 civil trials were held around the United States. In percentage terms, the decline was from $11.5 \%$ to $2 \%$ in civil trials commenced during that time period. See Galanter, supra note 8, at 459-60.

11. See id:; see also Mark R. Kravitz, The Vanishing Trial: A Problem in Need of Solution?, 79 ConN. B.J. 1, 45 (2005); Adam Liptak, U.S. Suits Multiply, but Fewer Ever Get to Trial, Study Says, N.Y. Times, Dec. 14, 2003, at A1. In 2006, 259,541 civil cases were filed in the federal courts, and 88,216 indictments were lodged against criminal defendants. See Admin. Office of the U.S. Courts, 2006 Judicial Business of the United States Courts 156 tbl. C, 214 tbl. D (2006), available at http:// www.uscourts.gov/judbus2006/completejudicialbusiness.pdf [hereinafter $2006 \mathrm{Ju}$ dicial Business]. In contrast, 12,612 civil trials, and 7,491 criminal trials took place. See 2006 Judicial Business, supra, at 198 tbl. C-7. 


\section{Pre-Democratic Adjudication}

Where did the practices of public adjudication come from? Below I quickly sketch-in part by showing pictures-several hundred years of history as I describe the didactic purposes of public courts. The next image (fig.2) helps to provide part of the answer. Reproduced is an engraved

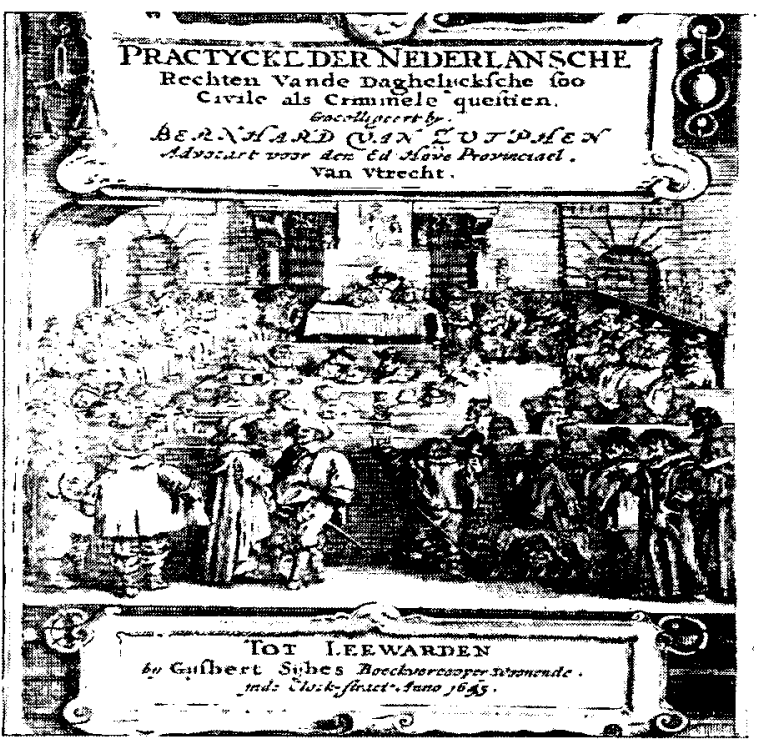

Figure 2. Engraved Title Page, Dutch Law and Practice in Civil and Criminal Matters (Practycke der nederlansche rechten van de daghelijcksche soo civile als criminele questien) Author: Bernhard van Zutphen, 1655 .

title page from a book published in 1655 by Bernhard van Zutphen; its English title is Dutch Law and Practice in Civil and Criminal Matters. ${ }^{12}$ Some spectators in the foreground talk with each other, while others are focused on the court proceedings. This same scene with minor variation can be found in several other volumes of that era. ${ }^{13}$ The densely populated

12. Zutphen was a prominent legal scholar who was well-known for his work on criminal law. See James $Q$. Whitman, The Moral Menace of Roman Law and the Making of Commerce: Some Dutch Evidence, 105 Yale L.J. 1841, 1867-71 (1995). My thanks to Michael Widener, Rare Book Librarian, Rare Book Collection, Lillian Goldman Law Library, Yale Law School, for bringing this image to my attention. Figure 2 is provided and reproduced courtesy of the Rare Book Collection, Lillian Goldman Law Library, Yale Law School.

13. Several variations can be found in seventeenth century Dutch law books. At least two have similar representations of Justice in the background. See JOHAN van den Sande, Rervm in SVPrema Frisiorum curia iudicatarum libri V [Five

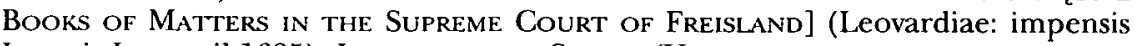
Ioannis Iansscnil 1635); JOHAN VAN DEN SANDE, (VIJF BOECKEN DER GEWJSDER SAKEN VOOR DEN Hove van VRIESLANDT [FIVE BOOKS ON LEgal ISSUES for THE CourT of FriesLand] (Leeuwarden, Eyvo Takus Wielsma 1670). Two other engraved title pages contain a similar court scene without a depiction of the Virtue Justice. See Jacob Coren, D. Lacobi Cooren in Supremo Senatu Hollandiae: Zeelandiae, FriSIAE, DUM VTVERET ASSESSORIS: OBSERVATIONES RERUM IN EODEM SENATU JUDICATARUM: ITEM CONSILIA QUAEDAM: AUCTIORA \& EMENDATIORA [COMMENTARY ON THE Decisions of The Supreme Court of Holland, Zeeland, and West-Friesland] (Amstelaedami: Apud J. Ravesteinium 1661); Hugo Grotius, INLEIDING TOT DE 
courtroom (complete with dogs in the front) shows the social space provided by town halls and their courts, which served as communal gathering spots.

A tiny figure stands behind the judge at the center. She is recognizable as "Justice" by virtue of her scales and sword. This icon has had an extraordinary run as political propaganda, spanning continents and centuries from then to now. ${ }^{14}$ That point can be made by continuing to use seventeenth-century Holland as an example and by moving from the printed page to buildings. A huge stone Justice (fig.3) crowns the tympa-

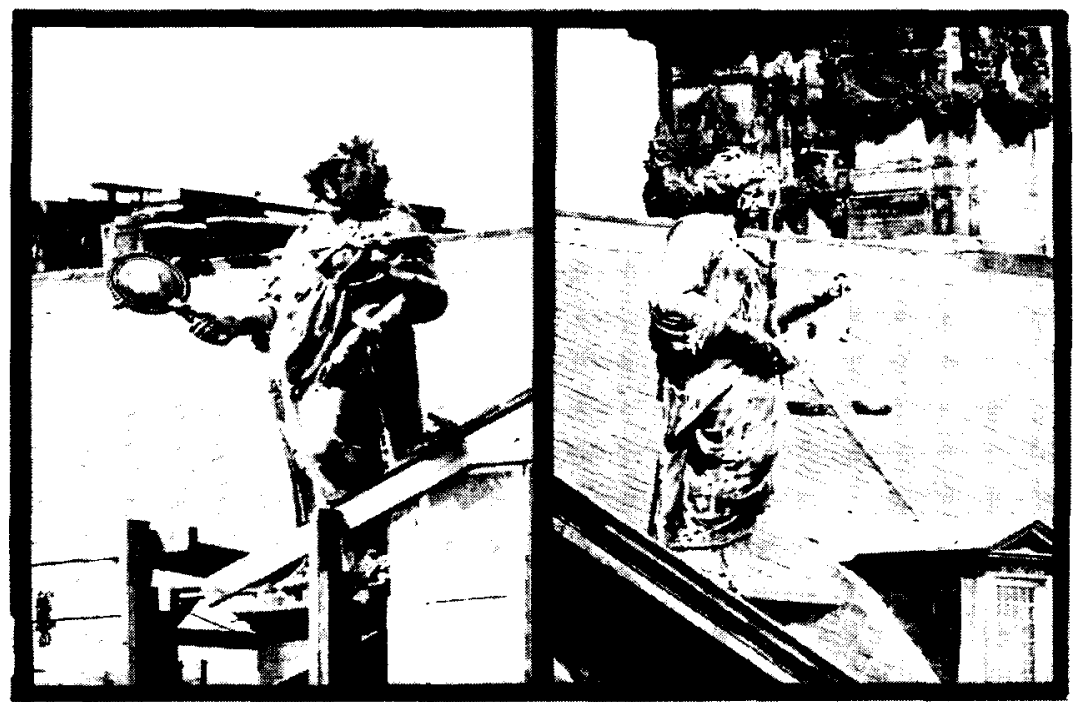

Figure 3. Prudence and Justice, attributed to Artus Quellinus, front tympanum of the Town Hall (Royal Palace) of Amsterdam, the Netherlands. Photograph reproduced with the permission of the Amsterdam City Archives.

num of the building, below the cupola facing Dam Square near the roof line of the Town Hall of Amsterdam, a multi-function building that served as that town's major courthouse and opened around the same time (1655) that the Zutphen book was published. ${ }^{15}$

A view of the façade (fig.4) enables one to grasp the enormity of the building on which this Justice stands. The Town Hall of Amsterdam (also called the Royal Palace) faces Dam Square. Remarkable for its grandeur,

HOLLANDSCHE RECHTS-GELEERTHEYD [INTRODUTION TO DUTCH LAW] (S'Graven-hage: By de weduwe van H.P. van Wou 1631).

14. See Resnik \& Curtis, Representing Justice, supra note †; Dennis E. Curtis \& Judith Resnik, Images of Justice, 96 YALE L.J. 1727 (1987).

15. Figures 3, 4, 5, and 6 of the Amsterdam Town Hall are reproduced with the permission of the Amsterdam City Archives and were obtained with the assistance of staff at the Amsterdam Historisch Museum and the Amsterdam City Archives. 


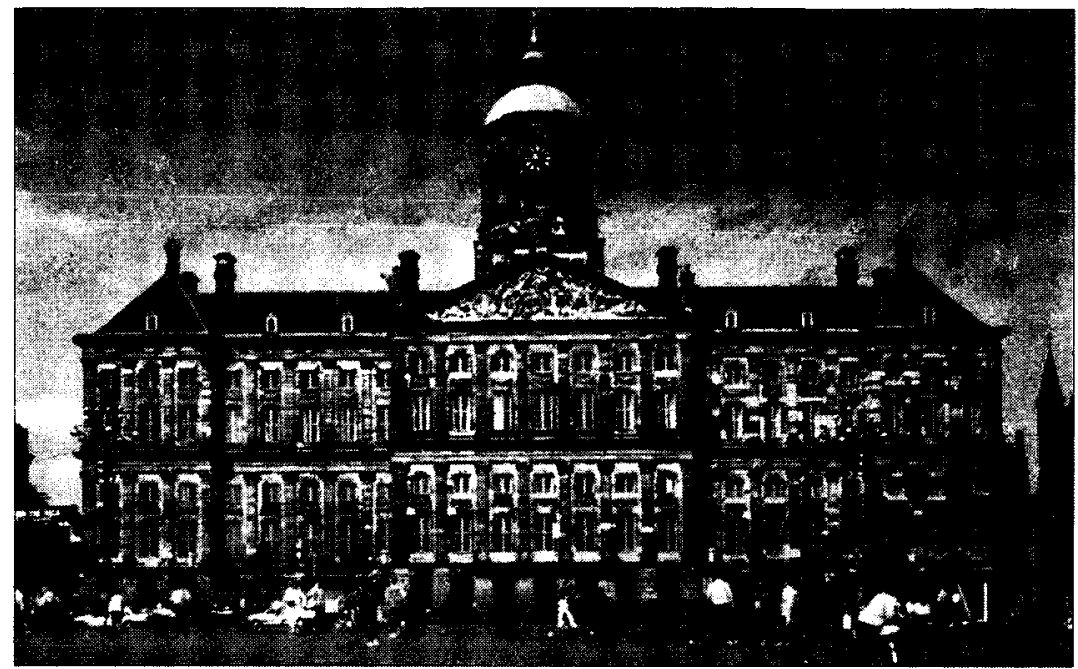

Figure 4. Exterior Shot of the Amsterdam Town Hall, 1648-1655. Architect: Jacob van Campen. Photograph reproduced with the permission of the Amsterdam City Archives.

this Town Hall was an "undertaking of megalomanic proportions" 16 and is exceptionally well-documented in the annals of art history. The Town Hall of Amsterdam is exemplary of much more ordinary spaces-hundreds of civic buildings around Europe that augmented churches and markets as places for communal activities.

These multi-purpose buildings typically included rooms for holding court and pronouncing judgments, as can be seen by turning to the next image (fig.5), which depicts the entrance to the Magistrates' Chamber. Everyone knew the purpose of this room because of the figure at the center of the display-another Justice with scales and a sword. Moving down to the ground floor, one finds a marble chamber (fig.6), with windows open to the street so that outsiders could watch what occurred within. ${ }^{17}$ This tribunal was the chamber where sentences of death were pronounced. ${ }^{18}$ From figure 7 , one can see what those looking in from

16. See Eymert-Jan Goossens, Treasures Wrought by Chisel and Brush: The Town Hall of Amsterdam in the Golden Age 12 (1996). The images of the west wall sculpture (fig.7) and the sculptures on it-King Solomon's Justice (fig.8), Zaleucus (fig.9) and Brutus (fig.10) - all attributed to Artus Quellinus, are reproduced with the permission of the copyright holder, the Royal Palace Foundation of Amsterdam. My thanks to the Royal Palace Foundation and to Dr. Eymert-Jan Goossens, who has also generously assisted me in the research on the Town Hall.

17. See Katharine Fremantle, The Baroque Town Hall of amsterdam 80 (1959).

18. The details of the ceremony are provided in Katharine Fremantle, The Open Vierschaar of Amsterdam's Seventeenth-Century Town Hall as a Setting for the City's Justice, 77 Oud Holland 206, 229-31 (1962). After the death sentence was announced, city bells rang and the sheriff went to the window of the "publication gallery," displayed the Rod of Justice and all sentences were read "out." Id. at 230. 

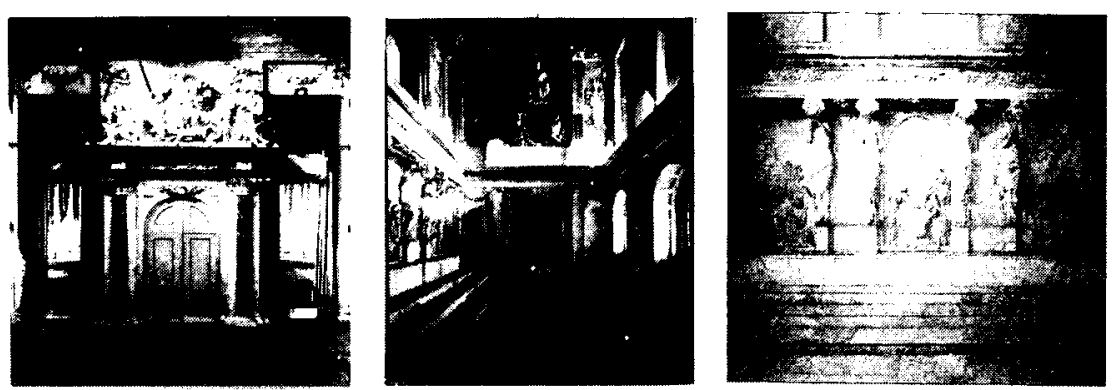

Figure 5 (left) Entrance to the Magistrates' Chamber; figure 6 (center) Interior of the Tribunal. Photographs reproduced with the permission of the Amsterdam City Archives. Figure 7 (right) Artus Quellinus, west wall sculpture, the Tribunal (circa 1655). Photograph copyright: Royal Palace Foundation of Amsterdam.

outside, as well as what the accused, faced-three stone reliefs telling Biblical, Greek and Roman stories.

What stories did the burgomasters who ruled in Amsterdam tell to those who watched their magistrates impose the death penalty? The center panel-King Solomon's Justice from the Old Testament (fig.8)-remains familiar. Next to Solomon was another then-commonplace scene in
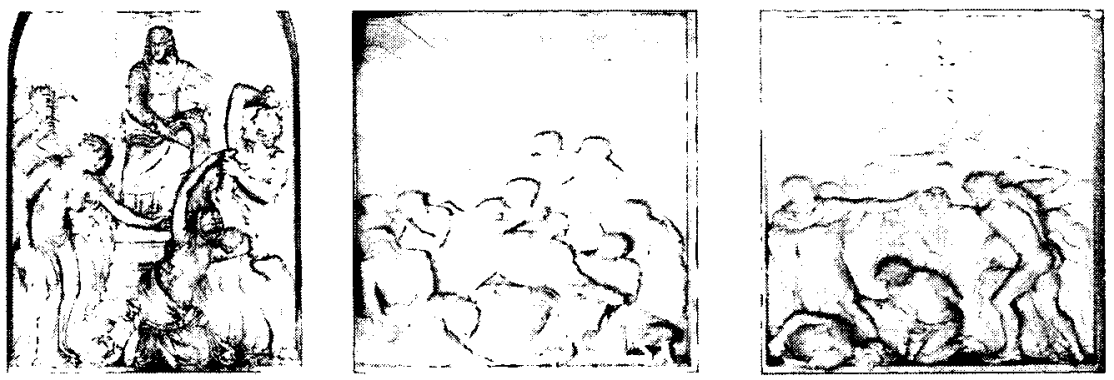

Figure 8 (left) King Solomon's Justice, figure 9 (center) Zaleucus; figure 10 (right) Brutus (circa 1655). Photographs copyright: Royal Palace Foundation of Amsterdam.

town halls that today is less readily recognized. Depicted is the Greek story of Zaleucus (fig.9), who was said to have found his own son guilty of violating his edicts. The punishment mandated was to gouge out the wrongdoer's eyes. At the behest of his counselors (goes the story), Zaleucus mitigated the penalty by having taken out one of his own eyes as well as one eye of his son. ${ }^{19}$ The third relief (fig.10) shows the Roman envoy,

19. The story, as told by Valerius Maximus, is excerpted below.

Nothing could be braver than the following examples of justice. Zaleucus protected the city of Locri with very salutary and useful laws. His son was convicted on a charge of adultery and according to a law constituted by Zaleucus himself was due to lose both eyes. The whole community wished to spare the young man the necessity of punishment in honour of his father. For some time, Zaleucus resisted, but in the end, overborne by the people's entreaties, he first gouged out one of his own eyes, then one of his son's, leaving the faculty of sight for them both. 
Brutus, ordering the death of his sons because they had joined a conspiracy against Rome. ${ }^{20}$

While the Town Hall of Amsterdam was, as noted, an extraordinary building, its content was not idiosyncratic. Rather, these scenes were placed on the walls of town halls around Europe. ${ }^{21}$ The normative lessons embodied in these allegories conveyed messages both authoritarian and utilitarian. These scenes instructed that obedience to the law of the state was required even at the price of personal pain, experienced not only by the accused but also by judges. Order your own sons to death to enforce the rule of the state. Gouge out his and your own eye.

Moreover, were one to forget who was in charge, another frequently shown scene-the Judgment of Cambyses (fig.11) - demonstrated the consequences of judicial misbehavior. The vivid diptych by Gerard David hung in the Town Hall of Bruges at the end of the fifteenth century. ${ }^{22}$ On a first panel, in a scene at the back, a corrupt judge, Sisamnes, is shown

2 Valerius Maximus, Memorable Doings and Sayings 64-65, 6:5 ext. 3 (D.R. Schackleton Bailey, trans., 2000 from a first century CE text) [hereinafter MEMORA. BLe Doings and Sayings]. A description was also provided in Gesta Romanorum, compiled during the first half of the fourteenth century in Latin and then translated in various European vernaculars. In that version, the "violated woman was a virgin" and a "daughter of a widow." See Jerzy Miziolek, Exempla Iustitiae at Arthur's Court in the Context of Dutch and Flemish, German, and Italian Art, in NeTHERLANDisH Artists In Gdansk In The Time Of Hans Vredeman De Vries 73, 77-78, 153 fig.9 (2006).

20. For an account of the story, see Livy, The EARly History of Rome 101, 1.60 (Aubrey De Sélincourt trans., Penguin Books 1975) and Memorable Doings AND SAYINGS, supra note 19, at 386-87, IV.4.1. A critical reading of Livy's account is provided in Ian Donaldson, The Rapes of LuCretia: A MYTH and ITS TransformaTIONS 110-12 (1982). Although the book bears the title of the story of Lucretia, its other focal point is the myth of Brutus as it traced the ways in which the two stories together purported "to explain the origins of the Roman Republic." Id. at 14.

21. A Judgment of Solomon was displayed, for example, in Alkmaar, Augsburg, Basel, Bremen, Breslau, Edam, Elbing, Frankfurt, Danzig, The Hague, Leyden, Leipzig, Lunenburg, Muenster, Rothenburg, Thorn, Ulm, and Ueberlingen.

Paintings of a Judgment of Zaleucus could be found in the Town Hall in Haarlem, Emden, Danzig, Hoorn, Eglisau, and in Nuremberg along with a Judgment of Solomon and likely a Cambyses. See generally Hugo van der Velden, Cambyses for Example: The Origins and Function of Exemplum Iustitiae in Netherlandish Art of the Fifteenth, Sixteenth and Seventeenth Centuries, 23 Simiolus: Netherlands QuarterLy fOr THE Hist. OF ART 19-20 (1995) [hereinafter Van der Velden, Cambyses for Example]. The imagery was also placed on medals. See Edward Gans \& Guido Kisch, The Cambyses Justice Medal, 29 ArT Bull. 121, 122 (1947). Scenes telling the Brutus story could be found in the Nuremberg Town Hall in a rendition by Hans Sebald Beham, in stained-glass window in Emden, and in the magistrates' chambers in Leiden in a painting by Karel de Moor, who lived in the second half of the seventeenth century. See Van der Velden, Cambyses for Example, supra, at 34 n.114.

22. See Hans Joris Van Miegroet, Gerard David 143 (1989); W.H. James Weale, Gerard David: Painter and Illuminator 6-7 (1895). See generally Van der Velden, Cambyses for Example, supra note 21; Hugo van der Velden, Cambyses Reconsidered: Gerard David's Exemplum Iustitiae for Bruges Town Hall, 23 Simiolus: NeTHERlands Quarterly For Hist. Art 40 (1995). These panels, Arrest of the Corrupt Judge (fig.11) and Flaying of the Comupt Judge (fig.12) that comprise The Justice (Judgment) of Cambyses are reproduced with permission from the copyright holder, Musea 
accepting a bag of money. In the foreground, that judge is removed from the bench at the behest of the ruling monarch, Cambyses, a figure in an ancient story told by Herodotus. ${ }^{23}$ The second panel (fig.12) features the judge being flayed alive. In the rear of that panel, the judge's son Otanes has been anointed the new judge and forced by Cambyses to assume the seat of power on a bench made from the skin of his father.
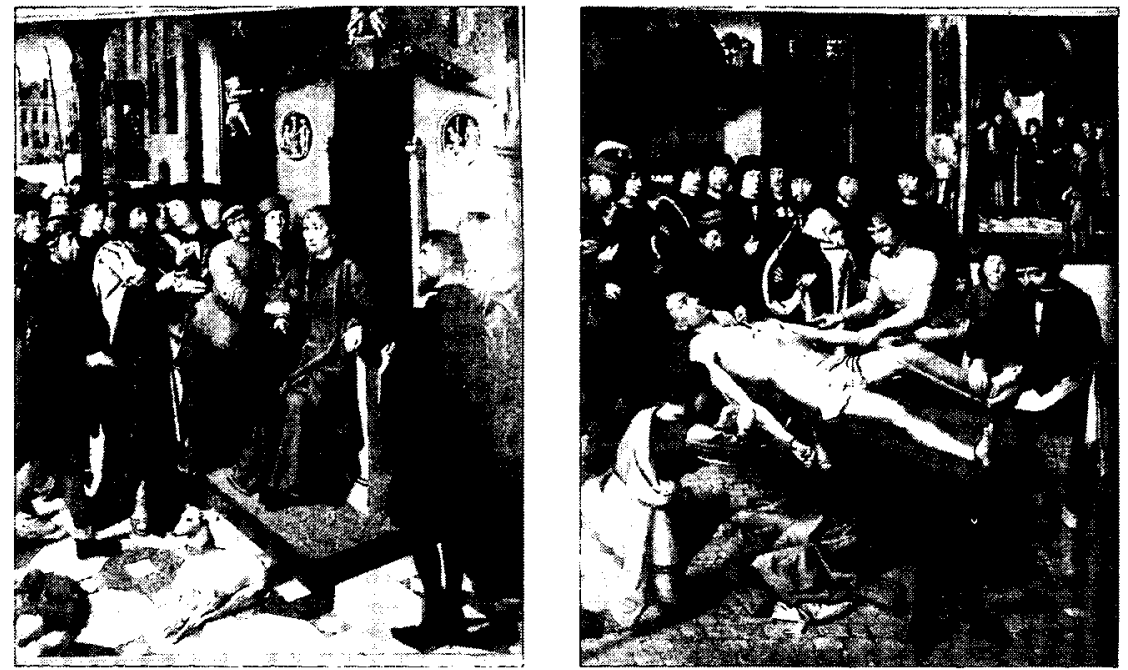

Figure 11 (left) Arrest of the Corrupt Judge, left panel, and figure 12 (right) Flaying of the Corrupt Judge, right panel of the diptych The Justice (Judgment) of Cambyses, Gerard David, 1498. Copyright: Musea Brugge, Groeningemuseum and reprinted with its permission.

The Cambyses story could be interpreted to be a decision of a lunatic, which-according to Herodotus-Cambyses was. But in Renaissance Europe, the story was mostly described as showing the "wise" king Cambyses in control of the corrupt judge. ${ }^{24}$ For example, in a major Danish tapestry commissioned by King Frederick II in 1581, Cambyses served as the exemplar of the prudent ruler. ${ }^{25}$

Brugge, Groeningemuseum. Thanks to Griet Teetaert at the Musea Brugge, for help in obtaining permission to reprint the panels.

23. Cambyses was the son of Cyrus the Great, who conquered Babylon in 539 BCE. Cambyses ruled from around 530 to 521 BCE. See Herodotus, 3 The HistoRIEs 95, 170, 171 (John Marincola ed., Aubrey de Selincourt trans., Penguin Classics 2003) [hereinafter Herodotus, Histories]; see also Geraldine Pinch, Egyptian Mythology: A Guide to the Gods, Goddesses, and Traditions of ANCIENT Egypt 34 (2002). Pinch noted evidence that a king who appeared to have been Cambyses existed and that he conquered Egypt in 525 BCE, but described the report that Cambyses had showed contempt for Egyptian gods by "stabbing the sacred Apis bull" to be a legend not substantiated by available evidence.

24. Gans \& Kisch, supra note 21, at 122; Van der Velden, Cambyses for Example, supra note 21 , at 11-16.

25. That tapestry, the Throne Baldachin, was woven by the Danish workshop at Helsingør from 1585 to 1586 . When finished, the tapestry consisted of a backcloth more than nine feet by eleven feet and a canopy of more than thirteen by 
Why should lawyers in the twenty-first century know about what pictures and carvings were placed in European town halls? These were public displays of political principles, provided through well-known narratives repeatedly told to judges, disputants, and to the general public about enforcing the law of the state. Why was adjudication public? Not because of democratic values about the political importance of transparent and accountable decision-making by governing powers. Rulers used these public rituals to show their power, insist on their capacity to command obedience, and give content to the practices with which they sought compliance.

The imagery can also be characterized as patriarchal or aristocratic. The familial scenes served to analogize rulers to parental figures, who were to be understood as obliged to impose punishments when violations of the law occurred but who took no joy from causing pain to their subjects/children. The sword held by the ubiquitous Justice reiterated the theme of law's power and its violence.

These juridical examples (in Latin, exempla iustitiae) help to make plain that pre-democratic adjudication ought not to be equated with adjudication under democratic precepts. These narratives insisted on judicial subservience rather than judicial independence. Only in later eras did a view develop that the judge was a specially-situated employee of the state, paid by the state yet insulated from its ordinary exercise of authority.

But glimmers of what is admired in both adjudication and democracy can also be found by looking back at this iconography of justice. The scales of Justice have something in common with political theories like democracy that impose constraints on power. Balancing and weighing reflect the idea that sheer power or arbitrary whim did not suffice to support legitimate exercises of state authority. Outcomes were supposed to be based on relevant facts intersecting with governing customs and rules. Moreover, forms of respect were owed to disputants. That point can also be found in texts literally etched into town halls, such as that shown in

nine feet that "was intended to hang above the royal table at which [Frederick II] and his wife, Queen Sophie, would sit." See Elizabeth Cleland, Throne Baldachin, in Tapestry in the Baroque: Threads of Splendor 33 (Thomas P. Campbell ed.) (catalogue to accompany an exhibit at the Metropolitan Museum of Art, 2008). Justice plays a prominent role, for she is depicted as a blond-haired centerpiece between the imagery celebrating the justice and greatness of the king and queen's lineages. Justice, in turn, is herself flanked by Temperance to the left and Fortitude to the right. In the canopy, classical "justice stories" are depicted on four medallions (id. at 34 ), including a medallion in which a crowned Cambyses gestures to the flayed body of Sisamnes that hangs above a judicial throne. The inscription below reads "CAmbysis vorsichtigkeit" (Cambyses Prudence). Id. at $\mathbf{3 5}$. From 1586 to 1658, the tapestry remained in the Danish Helsingør Castle. In 1658 , the troops of Swedish King Karl Gustav X removed it to Sweden. See Throne Baldachin, http://metmuseum.org/special/tapestry/view_l.asp?item=0 (last visited June 28, 2008). 
figure 13-the Latin phrase, Audi et Alteram partem-"hear the other side as well."26

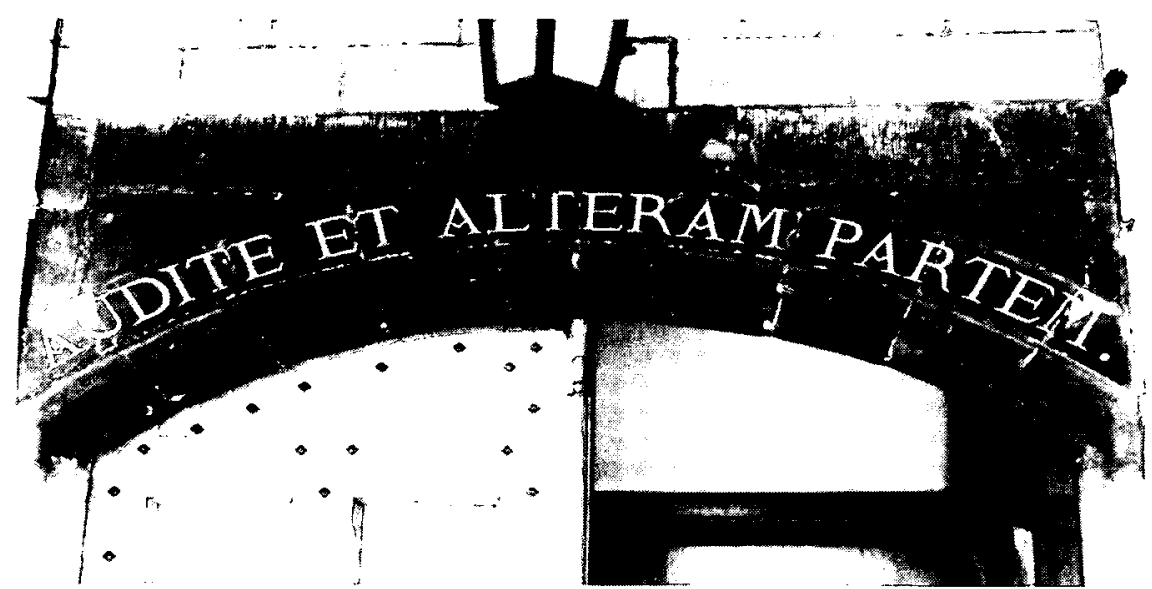

Figure 13. Arch of Entrance, Town Hall (Stadhuis), Gouda, 1449-1459. Architect: Jan Keldermans. Image reproduced courtesy of Regional Archive, Middle Holland Gouda, the Netherlands.

Further, echoing biblical injunctions, judges were told to treat the rich and the poor litigant alike and not to seek or to accept special favors. That message is made particularly stark in a 1604 fresco (fig.14), called Les Juges aux mains coupées (Judges with Their Hands Cut Off) from the Town Hall of Geneva. At one side of the handless judges is a banner inscribed with a warning from the Old Testament: that the taking of gifts "blindeth the wise, and perverteth the words of the righteous." 27 To summarize the tip of what is a vast visual iceberg, in the town halls that were also Medieval and Renaissance Europe's courts of law, governing powers displayed didactic messages aimed at instructing participants and spectators about their power to create order and to insist that everyone-those judged as well as those who were the judges-obeyed. These rulers relied on public

26. The photograph of the inscription over the arched entrance to the Gouda Town Hall (Stadhuis) (fig.13), is reproduced with permission of the copyright holder, the Regional Archive, Middle Holland, Gouda, the Netherlands. Thanks to Chavi Keeney Nana (Yale Law School, Class of 2009) and to Cristel Stolk and Joke Radstaatand of the Regional Archive for help in identifying and obtaining permission to reprint the image. The Town Hall of Amsterdam provides another example. See Fremantle, supra note 17, at 76 (describing phrase in gold lettering above the entrance to the Magistrates' Court).

27. See Natalie Zemon Davis, The Gift in Sixteenth-Century France 85 (2000) (providing translation of transcription, taken from Exodus 23:8). The fresco, from 1604 and by Cesar Giglio, was commissioned for the chambers; subsequent refurbishing covered the wall, and the image was not found again until 1901. See Barbara Roth-Lochner \& Livio Fornara, The Town Hall of Geneva 10-11 (Jean Gunn trans., 1986). Les Juges aux mains coupées (fig.14) is reproduced with the permission of Le Centre d'iconographie genevoise. Thanks to Ursula Baume-Cousam, Cäsar Manz, and Livio Fornara for help in obtaining permission to reprint. 
spectacles to make those claims, and much of their instruction was about their own very non-democratic power. ${ }^{28}$ Public performances of the rule of law helped to build and consolidate the authority of the state.

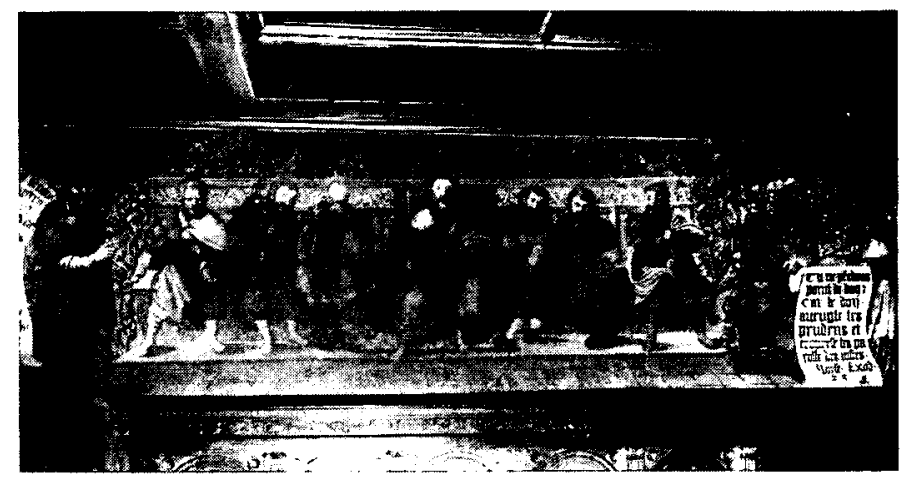

Figure 14. Les Juges aux mains coupées, Cesar Giglio, circa 1604, Salle du Conseil (Council Chamber), Town Hall of Geneva, Switzerland. Photograph reproduced courtesy of the Centre d'Iconographie Genevoise.

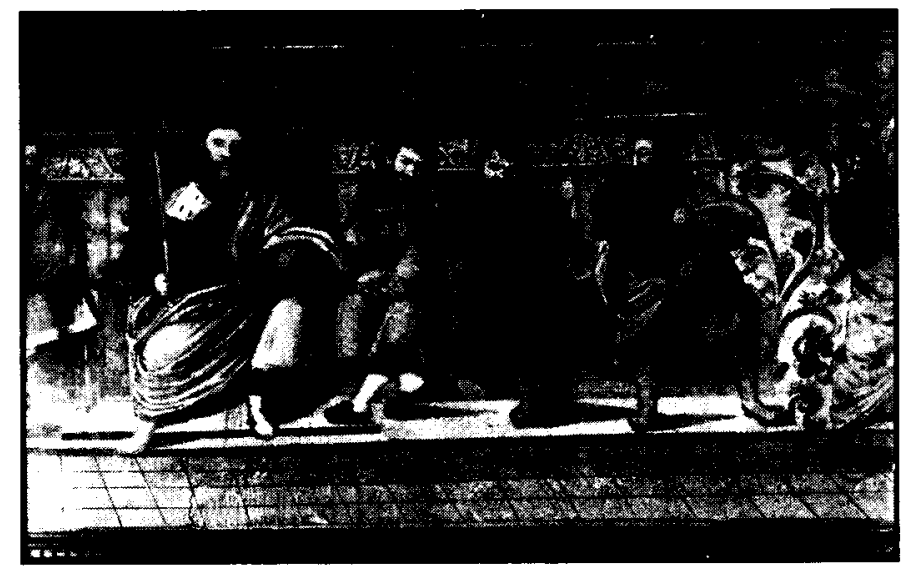

Detail: Les Juges aux mains coupées.

\section{Developing Democratic Norms}

But those who produce images and spectacles do not control their meaning or effects. As diverse audiences watched these displays, they came to develop views about legitimate decision-making - and came to believe that they had a role to play. Although the public displays were initially "rites" in which observers had no ability to make demands on rulers

28. Thus, and unlike some scholars of the trial-who have argued that "there was no political principle involved in the origins of the adversarial trial"-I think at least in the continent, the "political principle" was to demonstrate power. See Lindsay Farmer, Secret Trials and Public Justice (Fall 2007) (unpublished paper, on file with author). 
for what today we call "transparency" and "accountability," over time the audience moved into a more participatory stance.

Those shifts can be seen by moving forward to nineteenth-century England. Writing in the early part of that century, Jeremy Bentham insisted on the importance of what he called "publicity" in trials. What he said then is echoed regularly today when courts in the United States explain or insist on public processes. Bentham argued that public adjudication produced more accurate decisions. The wider the circle of dissemination of a witness's testimony, he posited, the greater the likelihood that a falsehood would be ferreted out: " $[\mathrm{m}]$ any a known face, and every unknown countenance, presents to him a possible source of detection." 29

Bentham also saw public processes as protection for, as well as against, judges. He urged that ordinary spectators be permitted to make notes that could be distributed widely. These "minutes" could serve as insurance for the good judge and as a corrective against "misrepresentations" made by "an unrighteous judge." 30 By suggesting that trials put the state (through its representative, the judge) on display, Bentham raised the specter that both judges and the state could be subjected to judgment.

This point is radical when measured against the baseline of Renaissance Europe, when people who observed trials were not presumed to hold the power to sit in judgment of judges or to assess the decency of the state's procedures. By Bentham's time, however, the audience was no longer conceptualized in as passive a role as that of spectator. The responses of observers had weight and relevance as popular opinions came to matter through the development of a "public sphere" that could affect political rulers. ${ }^{31}$

Bentham believed that the public features of adjudication would generate a desirable form of communication between citizen and the state. Bentham did not suggest imposing a legal obligation on judges to "deliver" opinions but he thought that, when judges gave decisions in public, they would want their audience to understand the reasons behind their judicial actions. Thus, it would be "natural" for judges to gain "the habit of giving reasons from the bench." 32

29. See Jeremy Bentham, Chapter $X$ "Of Publicity and Privacy, as Applied to Judicature in General, and to the Collection of the Evidence in Particular, " in 6 THE WORKs of Jeremy Bentham 351, 355 (William Tait, 1843).

30. Id.

31. See Jürgen Habermas, The Structural Transformations of the Public SPHERE: AN INQUiRY INTO A CATEgory of Bourgeois SOCIETY (Thomas Burger trans.,1989); David Zaret, Origins of Democratic Culture: Printing, Petitions, and the Public Sphere in Early-Modern Encland (2000). See generally Habermas and the Public Sphere (Craig Calhoun ed., 1992); Luke Goode, Jürgen Habermas: Democracy and the Public Sphere (2005).

32. BENTHAM, supra note 29 , at 357. 


\section{Democracy's Transformation of Adjudication}

Bentham is, of course, part of a broader picture of transformations in social orders that took place during the last three centuries. As Michel Foucault has famously recounted, given that open processes of punishment produced opportunities for an "unruly crowd" to vent distress, punishment was privatized to enhance the ability of the state to reassert control and discipline. ${ }^{33}$ Yet, some aspects of displaying the spectacle of adjudication became sufficiently entrenched that they turned into obligations.

The proposition that judicial power entails an open process moved from being a means to an end in itself, as can be seen from the text of the American Constitution-with its Sixth Amendment establishing that the accused has a right to a "public trial." ${ }^{34}$ Many state constitutions go further by making explicit rights of access through "open" or "public" courts. ${ }^{35}$ In the twentieth century, Article 6 of the European Convention on Human Rights demonstrated the transnational codification of this principle. In 1950, it set forth the proposition that "[i]n the determination of his civil rights and obligations or of any criminal charge against him, everyone is entitled to a fair and public hearing within a reasonable time by an independent and impartial tribunal established by law." 36 Of course, such provisions also recognize the legitimacy of closures-as had Bentham-under specified circumstances. ${ }^{37}$

33. Michel Foucault, Discipline and Punish: The Birth of the Prison 8 (Alan Sheridan trans., 2d ed. 1977).

34. U.S. Const. amend. VI. The Sixth Amendment provides:

In all criminal prosecutions, the accused shall enjoy the right to a speedy and public trial, by an impartial jury of the State and district wherein the crime shall have been committed, which district shall have been previously ascertained by law, and to be informed of the nature and cause of the accusation; to be confronted with the witnesses against him; to have compulsory process for obtaining witnesses in his favor, and to have the Assistance of Counsel for his defence.

Id. See generally Richmond Newspapers, Inc. v. Virginia, 448 U.S. 555 (1980).

35. See, e.g., Conn. Const. art. 1, 110 ("All courts shall be open, and every person, for an injury done to him in his person, property or reputation, shall have remedy by due course of law, and right and justice administered without sale, denial or delay."); S.C. ConsT. art. I, $\$ 9$ ("All courts shall be public, and every person shall have speedy remedy therein for wrongs sustained.").

36. Convention for the Protection of Human Rights and Fundamental Freedoms, Sept. 3, 1953, 213 U.N.T.S. 221 [hereinafter European Convention on Human Rights]; see also Article 14 of the International Covenant on Civil and Political Rights, G.A. Res. 2200A (XXI), U.N. Doc. 1/6316 (1966) ("Everyone shall be entitled to a fair and public hearing by a competent, independent and impartial tribunal established by law.").

37. See, e.g., European Convention on Human Rights, supra note 36, art. 6(1) ("Judgment shall be pronounced publicly but the press and public may be excluded from all or parts of the trial in the interests of morals, public order or national security in a democratic society, where the interests of juveniles or the protection of the life of the parties so requires, or to the extent strictly necessary in 
Pierre Bourdieu's term "reflexivity" is apt, in that the practices of open courts have become a signature feature that helps to define an institution as a court. ${ }^{38}$ Moreover, rights of publicity are not limited only to proceedings denominated as "trials" but, through constitutional and common law elaboration, ${ }^{39}$ also apply to provide the public with access to other forms of evidentiary hearings and to court records. ${ }^{40}$ New techniques of dissemination have also been developed. ${ }^{41}$ In addition to the open doors and windows of courtrooms, during the twentieth century, the rise of the newspaper business and of the commercial publication of decisions created more ways in which knowledge about what took place in courts came before the public.

Today's technologies have many times amplified the possibilities. In addition to the web and electronic databases, some jurisdictions televise court proceedings. We can be "virtual" observers by watching from our own homes through televised proceedings from, for example, the Supreme Court of Canada, ${ }^{42}$ the International Criminal Tribunal for the

the opinion of the court in special circumstances where publicity would prejudice the interests of justice.")

38. See Pierre Bourdieu, The Force of Law: Toward a Sociology of the Juridical Field, 38 Hastings L.J. 815, 838 (Richard Terdiman trans., 1987).

39. See, e.g., Press-Enter. Co. v. Super. Ct., 478 U.S. 1 (1986); see also Hartford Courant Co. v. Pellegrino, 380 F.3d 83, 96 (2d Cir. 2004) (holding that "docket sheets enjoy a presumption of openness and that the public and the media possess a qualified First Amendment right to inspect them" and explaining utility of such an approach).

40. See generally Judith Resnik, Due Process: A Public Dimension, 39 U. Fla. L. Rev. 405 (1987); see also Joseph F. Anderson, Jr., Secrecy in the Courts: At the Tipping Point?, 53 VilL. L. REV. 811 (2008).

41. See generally Peter W. Martin, Online Access to Court Records-From Documents to Data, Particulars to Patterns, 53 VILL. L. Rev. 855 (2008). Making different forms of information available does not necessarily make all decision-making transparent.

42. In Canada, Supreme Court proceedings are televised. As to the method, most "courtroom proceedings are televised by the Canadian Parliamentary Affairs Channel (CPAC)." See Supreme Court of Canada, Frequently Asked Questions, http://www.scc-csc.gc.ca/faq/faq/index_eng.asp\#f7 (last visited June 28, 2008). See generally A. Wayne MacKay, Framing the Issues for Cameras in our Courtrooms: Redefining Judicial Dignity and Decorum, 19 Dalmousie L.J. 139 (1996) (exploring whether, under Section 2(b) of Canadian Charter of Rights, providing for freedom of press and of expression, electronic media ought to have access to court proceedings). For an exploration of how such technologies affect the content and meaning of trials, see Linda Mulcahy, An Unbearable Lightness of Being? Shifts Towards the Virtual Trial (paper presented at the Birkbeck College Symposium, Adjudicatory Practices in Transition: Courts and the Public Sphere, to be published at 35 J.L. Soc'y. (forthcoming 2008, manuscript on file with author). 
Former Yugoslavia, ${ }^{43}$ and a few of the states in America. ${ }^{44}$

Furthermore, these rights reflected a shift in theories of sovereignty that made untenable the proposition that judges were the loyal servants of the state, subject to the power of the crown. Rather, judges came to be understood as occupying a unique role, authorized to sit in judgment of the very power that employed them. The 1701 Act of Settlement in England is one form of that independence, ${ }^{45}$ and Article III of the United States Constitution-promising judges tenure during good behavior and salaries protected against diminution ${ }^{46}$-offers another. Like the publicity aspects of courts, judicial independence also became definitional of courts in democracies. Moreover, these two facets-judicial independence and public proceedings-interact. Open processes serve as a mechanism to make plain that a government must acknowledge the independent power of the judge, or open processes can reveal state efforts to try to impose its will on judges.

Yet some aspects of adjudication post-democracy are continuous with its history pre-democracy. I will detail this point through a focus on the United States. Just like the burgomasters of Amsterdam, the federal government also sought to use its economic wherewithal and its power to establish big public spaces both to make and to mark its power. Its buildings and its public displays of law enforcement were a means to an end: creating a unified nation with central authority residing in the federal government.

Specifically, in the aftermath of the Civil War, Congress repeatedly turned to the federal courts as instruments of enforcement of federal norms. One technique of generating "a federal presence" 47 was to con-

43. All proceedings other than deliberations "shall be held in public, unless otherwise provided." Rule 78 (Open Sessions), Rules of Procedure and Evidence, ICTY, IT/32/Rev.36, available at http:/www.un.org/icty/legaldoc-e/index.htm (follow "Rules of Procedure and Evidence rev. 36" hyperlink). When needed for protection of victims or witnesses or for reasons of security or justice, the trial chambers may make provisions for private or in camera processes. See id. at Rule 75 (Measures for the Protection of Victims and Witnesses), Rule 79 (Closed Sessions). Full transcripts-and when appropriate, video recordings-are made. See $i d$. at Rule 81 (Records of Proceedings and Evidence). The tribunal's working languages are English and French; in addition, the accused has a right to use his or her own language. See id. at Rule 3(B) (Languages). Transmission is provided via weblink, enabling the public, including people in the former territories, to see the proceedings; the languages offered include French, English and Serbo-Croatian. When witnesses or proceedings raise security problems, the screened images are scrambled as may be the voices of witnesses. See id. at Rule 75 (B) (i) (c) (Measures for the Protection of Victims and Witnesses).

44. See Robert L. Brown, Just a Matter of Time? Video Cameras at the United States Supreme Court and the State Supreme Courts, 9 J. App. Prac. \& Process 1 (2007).

45. Act of Settlement, 1701, $12 \& 13$ Will. 3, c. 2 (Eng.).

46. U.S. Const. art. $3, \S 1$; cl. 2.

47. This phrase comes from the title of a book. See Lois Craig, The Federal Presence: Architecture, Politics, and Symbols in United States Government BuILDING (1978). 
struct federal buildings around the United States. Between 1852 and 1939, construction was under the superintendence of the Office of the Supervising Architect in the Treasury Department.

In the initial phase, those federal buildings were, like the town halls of the Renaissance, multi-purpose spaces. ${ }^{48}$ Through the work of the Federal Judicial Center (the FJC), we know that these multi-purpose buildings ("combining the functions of courthouse, customhouse, and post office") were aimed at extending "the authority of the federal government to every region of the country." 49 Towns and cities sought to be the sites for federal offices as sources of commercial development, and the new "handsome buildings ... offered prestige to the federal courts, which previously had met in an assortment of state offices and rented buildings." ${ }^{50}$

The title of this Lecture refers to courts in "sight" and in "site." Thus, I provide a few pictorial examples of this building project that crisscrossed the country during the course of almost one hundred years. The selection starts with an 1861 federal building (fig.15) funded in Galveston soon after Texas became a state. ${ }^{51}$ Another example comes from a 1913 building (fig.16) in Missoula, Montana that a local paper described as an "ornament to the city." 52 This travelogue continues in

48. In terms of administration of these buildings, in 1849 Congress created a federal Department of Interior, charged with the management of public lands and parks. That department also took on the fiscal responsibility for the administration of the very small federal court system as it then existed. See The Federal Judicial Center, Executive Agencies and Judicial Administration, Executive Branch Administration of the Federal Judiciary, http://www.fjc.gov/history/home.nsf (last visited June 28,2008 ). When the Department of Justice was created in the later part of the nineteenth century, it took over the administrative activities related to courts and, in 1939, Congress created the Administrative Office of the U.S. Courts to oversee the judicial branch's budgets, facilities, and personnel.

49. See Federal Judicial Center, Constructing Justice: The Architecture of Federal Courthouses 1-3 (A Description of Historical Photographs Exhibited at the Federal Judicial Center, undated essay) and Constructing Justice: An Exhibit of Courthouse Photographs at the Federal Judicial Center, 8 The Court Historian 1 (1995) (hereinafter Constructing Justice). The set of photographs is also available through an online database available at http://www.fjc.gov/history/courthouses.nsf.

50. Constructing Justice at 1.

51. Texas became independent from Mexico in 1836, was later annexed by the United States, and in 1845 given statehood.

52. These images of historic courthouses-in Galveston, Texas (fig.15), Missoula, Montana (fig.16), San Diego, California (fig.17), and San Juan, Puerto Rico (fig.18) - can be found at Federal Judicial Center ("FJC"), Historic Federal Courthouses, http://www.fjc.gov/history/courthouses.nsf (last visited June 28, 2008). Thanks are due to Steven G. Saltzgiver, FJC Research Historian, and Bruce A. Ragsdale, Director of the History Office of the FJC, for help in locating and reproducing these photographs. 

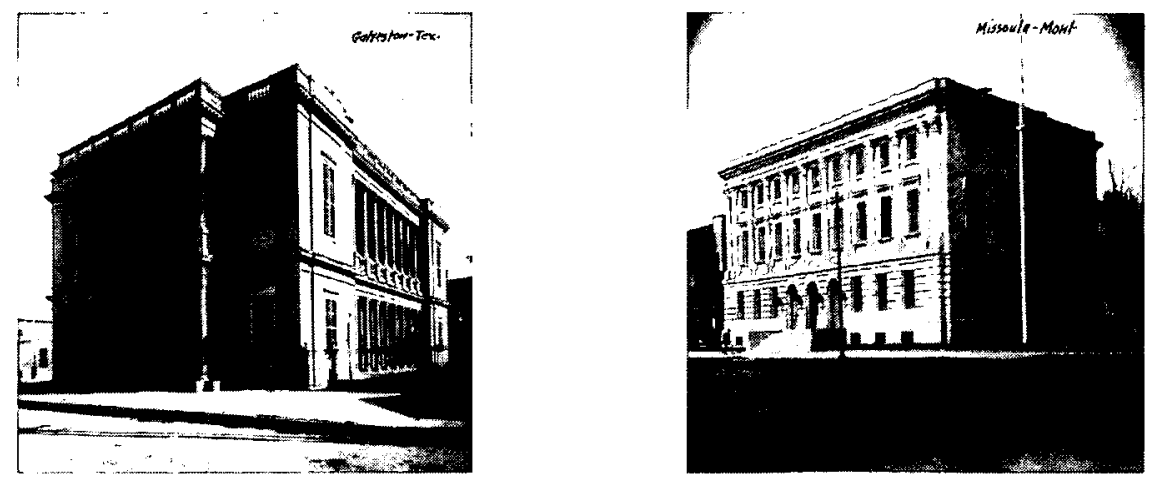

Figure 15 (left) United States Customhouse, Galveston, Texas, 1854 1861. Supervising Architect: Ammi B. Young. Figure 16 (right) United States Federal Building, Post Office, and Courthouse, Missoula, Montana, 1911-1913. Supervising Architect: James Knox Taylor. Images courtesy of the National Archives and Records Administration.

San Diego, California (fig.17) in 1913 and then moves east, where in 1914, a new courthouse was provided for the territorial court (fig.18) in San Juan, Puerto Rico.

This brief tour around the United States aims to make plain that, despite variations in style, a reiterated motif is the construction of important public spaces representing federal authority. As all those windows and doors also suggest, the federal buildings were readily accessible to foot traffic, from the litigant to the person mailing a letter. And up until the 1980s, one could enter those buildings freely without emptying one's
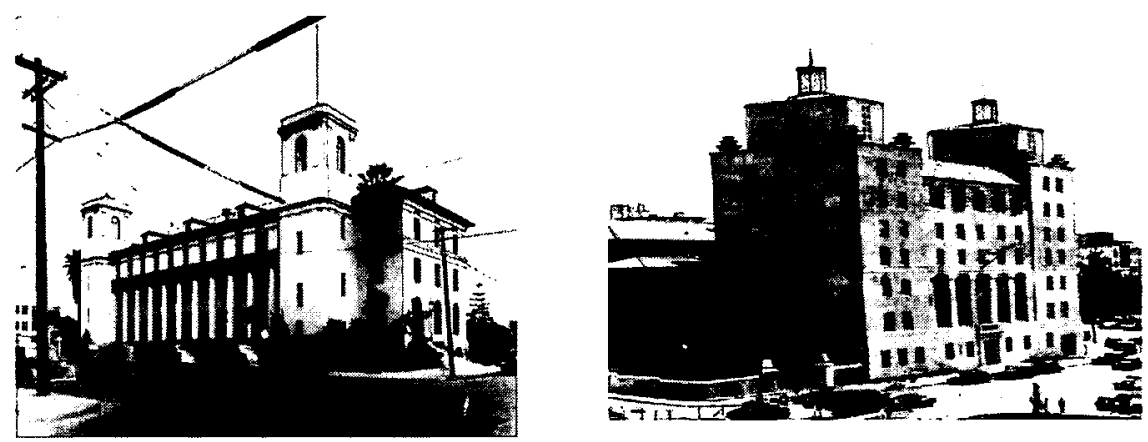

Figure 17 (left) United States Post Office and Customhouse, 19111913, renovated 1994, renamed in 1986 the Jacob Weinberger United States Courthouse, San Diego, California. Supervising Architect: James Knox Taylor. Figure 18 (right) United States Post Office and Courthouse, 1911-1914, enlarged 1938-1940, renamed in 1999 the Jose V. Toledo Federal Building and United States Courthouse, San Juan, Puerto Rico. Supervising Architect: James Knox Taylor. Images courtesy of the National Archives and Records Administration. 
pockets or passing screening devices. Over the decades, the construction of multi-purpose government spaces became more unusual, and buildings gained a singular identity as courthouses. What is now familiar to us was novel not too many centuries or even decades ago. The courthouse-as a segregated and specially named space ${ }^{53}$ separate from the post office, the customs house, and the jail-was once uncommon.

What is implicit in this rendition of buildings is another point: that these building programs also tell us something about the demand for adjudication (as well as for postal services). The examples from San Diego and Puerto Rico show courthouses sprouting beyond the three to fourstory models. The development of democracy changed the needs for, access to, and modes of adjudication. Moreover, democracy opened up the prospect of justice-seeking for wholly new sets of claimants, who gained rights to use litigation to call state officials to account in order to hold government to its own promises. The result has been an avalanche of claims, ranging from veterans seeking benefits within administrative tribunals to victims of crimes against humanity seeking acknowledgment in domestic as well as in international courts for wrongdoing of horrific dimensions.

The size and scale of cases has changed as well. In part through new information technologies, patterns of injuries experienced by large numbers of individuals became visible, permitting us to connect incidents heretofore perceived as isolated or idiosyncratic events. When once we spoke of a "case," now we use the term "litigation"-the asbestos litigation, tobacco litigation, Agent Orange litigation-capturing an enormous array of parties and of varying forms of injury. Aggregation of claimants and mass-provided remedies - through various mechanisms ranging from class actions to administrative grids-are key facets of modern legal life that have altered the resources of the participants and the stakes. ${ }^{54}$ Further, the growth of the profession of lawyers provided the personnel that both fueled and staffed the regulatory state and ferreted out aggregate forms of injury. The transformation of the legal profession is a story unto itself, but its expansion and diversification is a predicate to demands for judging.

Another factor, one that has been underappreciated in the literature of courts, is women's rights. One can see many images of Justice as a woman but women themselves could not, in many countries in many periods, participate in courts as judges, jurors, witnesses or litigants. Women only gained full juridical voice in the last century, and the radical reconception

53. See generally Clare Graham, Ordering Law: The Architectural and Soclal History of the English Law Court to 1914 (2003).

54. See, e.g., Judith Resnik, From "Cases" to "Litigation", 54 Law \& ContemP. Probs. 5 (1991); Judith Resnik, Dennis E. Curtis \& Deborah Hensler, Individuals Within the Aggregate: Relationships, Representations, and Fees, 71 N.Y.U. L. Rev. 296 (1996). 
of women as rights-holders-both in and outside of their families-has driven up the volume of disputes. ${ }^{55}$ When women of all colors join a growing circle of "persons" of all ages and ethnicities as well as groups themselves, one can see part of why the demand side has soared. ${ }^{56}$

A recap of the changing landscape can quickly be seen through a bar graph and a few more pictures. A simple graph (fig.19) maps the growth

Article III Authorized Judgeships: District, Circuit, and Supreme Courts: 1901,1950 , and 2001

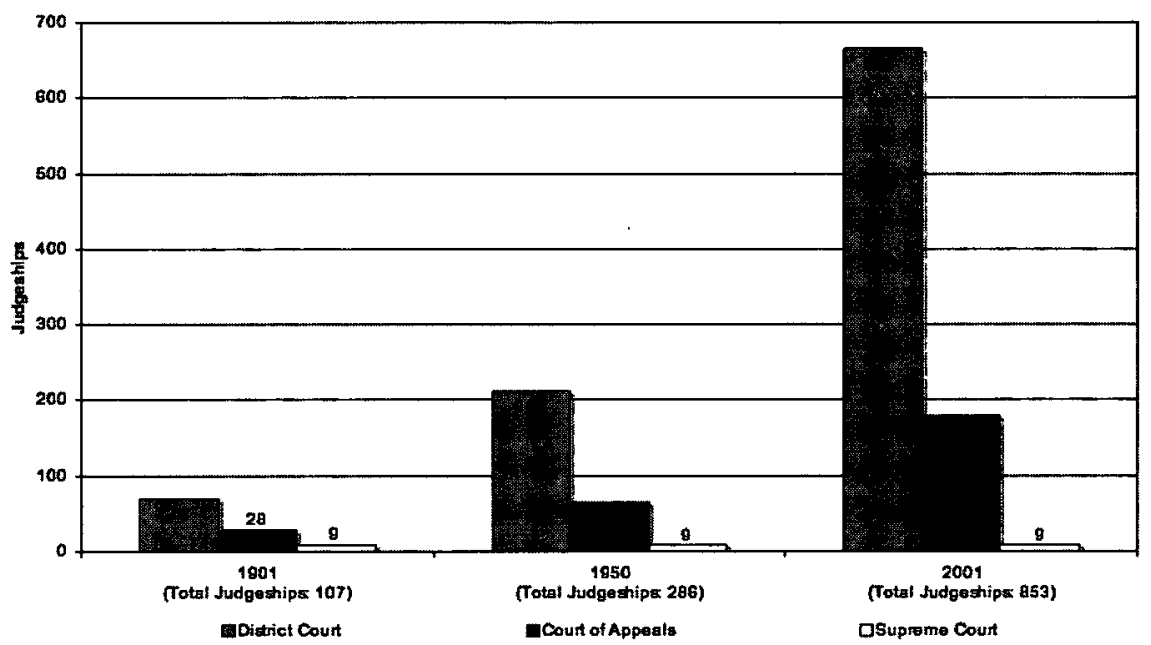

Figure 19. Copyright Judith Resnik, 2007

in only the life-tenured federal trial judges in the United States over about one hundred years. The number of authorized judgeships rose from under 100 in 1901 to now more than 650 .

55. Whole fields of litigation-and most vividly "family law"-though now taken for granted, did not much exist in the nineteenth century.

56. The changing composition of litigants has produced new criteria for judicial selection. While once all the judges were of one class, race, ethnicity and sex, today in countries around the world and in transnational courts, the call is for a "diverse" judiciary. See Judith Resnik, Judicial Selection and Democratic Theory: Demand, Supply, and Life-Tenure, 26 CARDozo L. REv. 579 (2005). 
In days of fewer federal filings and fewer federal rights, United States federal courthouses like the 1906 building (fig.20) ${ }^{57}$ in Grand Forks, North Dakota sufficed.

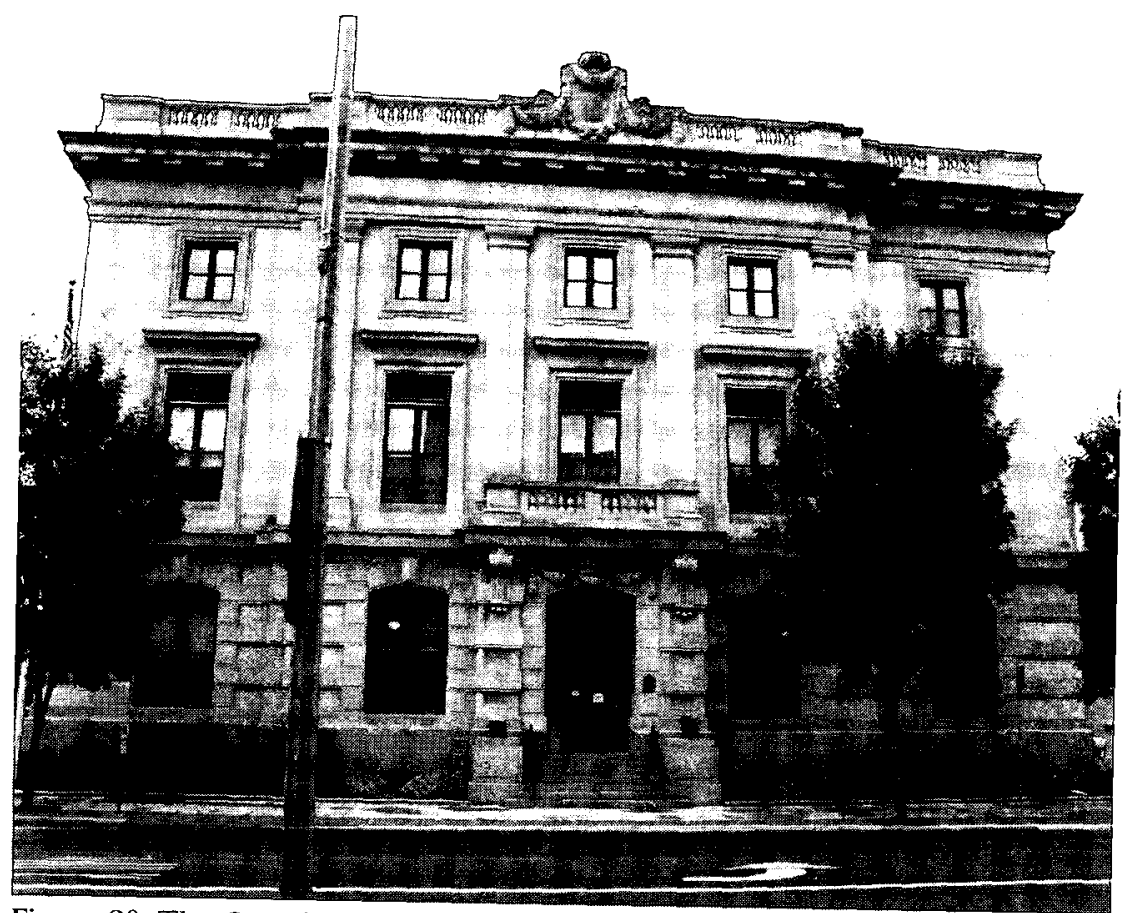

Figure 20. The Grand Forks Federal and Court Building, 1906, renamed in 2002 the Ronald N. Davies Federal Building and U.S. Courthouse, Grand Forks, North Dakota. Architect: James Knox Taylor. Copyright: Steve Silverman, www.stevesilvermanimaging.com.

57. The photograph of the front exterior view of the Grand Forks Federal and Court Building (fig.20), taken by Steve Silverman, is reproduced with his permission and the permission of the building's Property Manager, Bryan Sayler. Photograph copyright: Steve Silverman, www.stevesilvermanimaging.com. The Honorable Celeste Bremer, Magistrate Judge, Southern District of Iowa, and Janice Dinkel, Judiciary Regional Account Manager, Public Buildings Service, GSA Rocky Mountain Region, enabled us to obtain this image. 


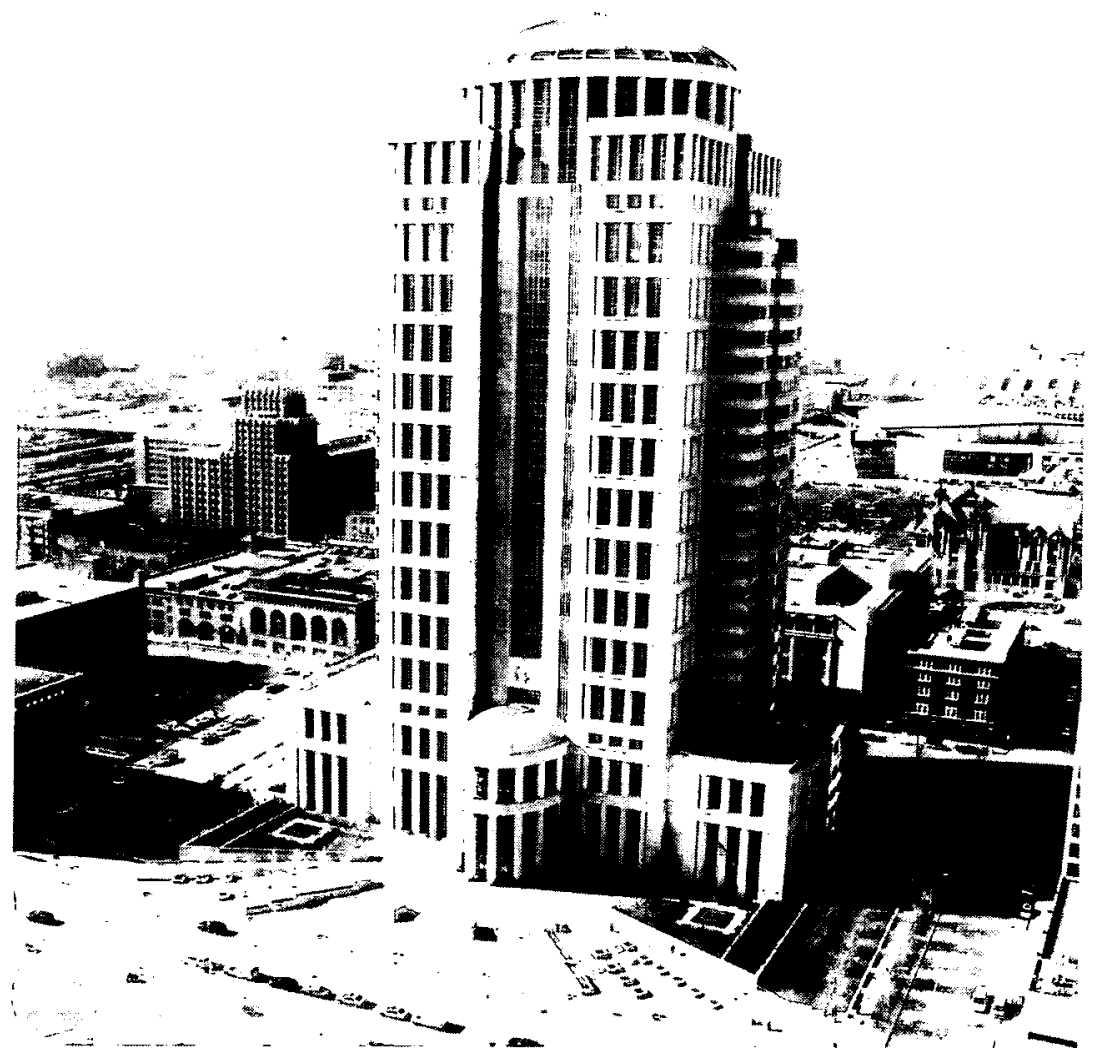

Figure 21. Thomas F. Eagleton Federal Courthouse, St. Louis, Missouri, 2000. Photograph courtesy of and reproduced with permission of the photographer.

In contrast, by 2000, a skyscraper provided a new federal courthouse in St. Louis, Missouri (fig.21) - the tallest in the nation. ${ }^{58}$ In Boston, another major building opened in 1998. The several-story new federal courthouse was designed by Henry Cobb,

58. The Thomas F. Eagleton U.S. Courthouse (architect: Hellmuth, Obata, + Kassabaum), twenty-nine stories high and containing over a million square feet square feet, is described on the GSA website as the "largest single" federal courthouse built. See U.S. General Services Administration, Thomas F. Eagleton U.S. Courthouse, http://www.gsa.gov (search "Thomas Eagleton"; follow courthouse hyperlink) (April 24, 2008). The courthouse cost $\$ 200,000,000$ to construct and opened in 2000. See City of St. Louis Development Activity, Eagleton Federal Courthouse, http://stlcin.missouri.org/devprojects/projinfo.cfm?DevProjectID= 47 (last visited June 28, 2008). The photograph is provided by Magistrate Judge David Noce of the Eastern District of Missouri and is reproduced with his permission as copyright holder. 
with vivid color panels by the artist Ellsworth Kelly (fig.22).$^{59}$ In the Boston
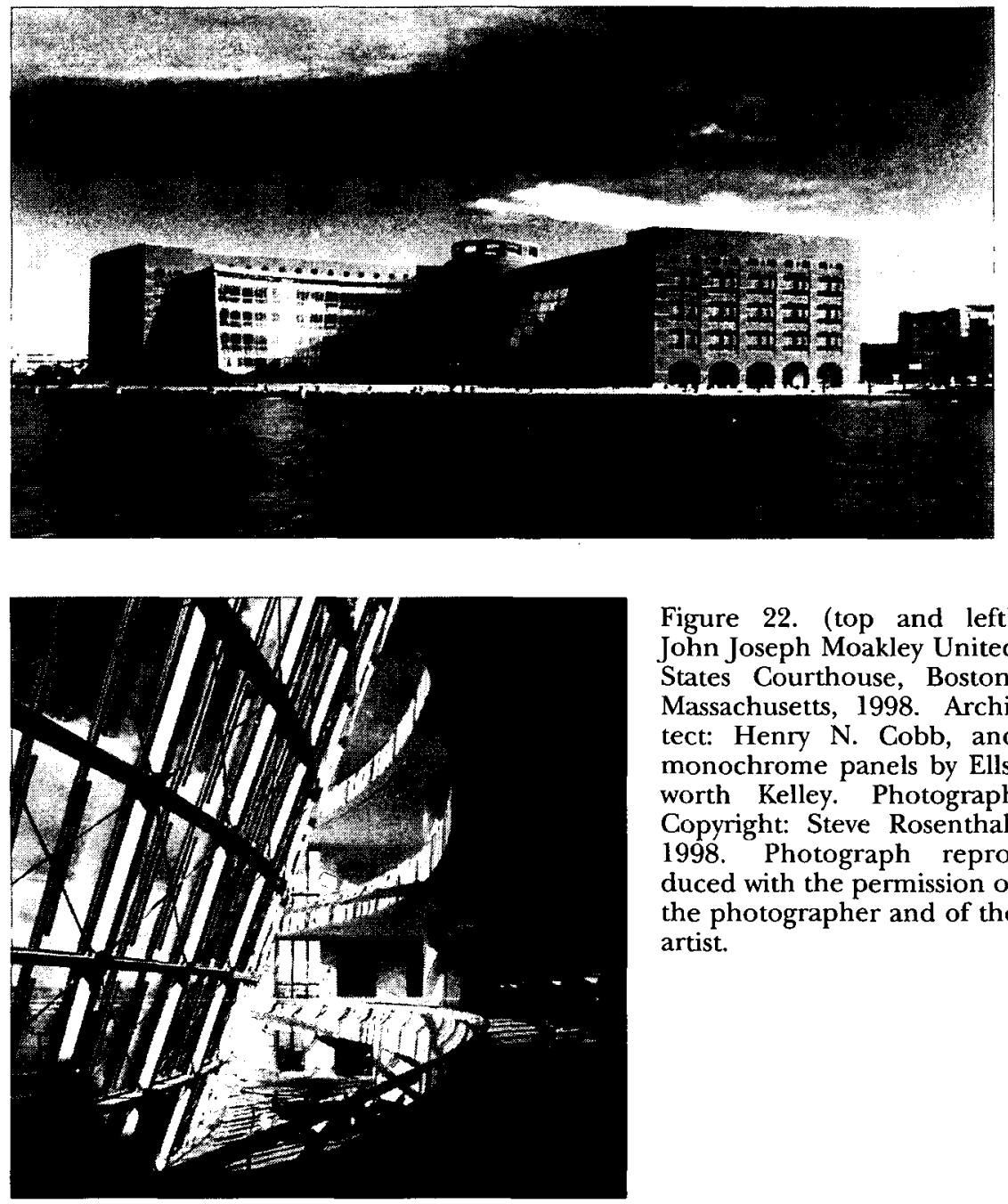

Figure 22. (top and left) John Joseph Moakley United States Courthouse, Boston, Massachusetts, 1998. Architect: Henry N. Cobb, and monochrome panels by Ellsworth Kelley. Photograph Copyright: Steve Rosenthal, 1998. Photograph reproduced with the permission of the photographer and of the artist.

59. See Stephen G. Breyer, Foreword to Celebrating the Courthouse: A Guide for Architects, Their Clients, ANd the Public 9-12 (2006) [hereinafter Celebrating the Courthouse]; Douglas P. Woodlock, Drawing Meaning from the Heart of the Courthouse, in CeIEBRATING THE CourTHOUSE, supra at 155-167; see also Douglas P. Woodlock, The "Peculiar Embarrassment": An Architectural History of the Federal Courts in Massachusetts, 74 Mass. L. REv. 268-78 (1989); Douglas P. Woodlock, Lecture: The New Federal Courthouse in Boston (1995) (on file with author). Photograph copyright: Steve Rosenthal, 1998. The photographs of the interior of the John Joseph Moakley United States Courthouse (figs.22 \& 23) were taken by Steve Rosenthal and are reproduced with his permission and that of the artist Ellsworth Kelly, and obtained with the assistance of the Honorable Douglas P. Woodlock, United States District Judge of the District of Massachusetts. 
courthouse, twenty-five trial courts look more or less like this one (fig.23), aiming to make a space that exemplifies the idea of law as accessible. The designers of this courthouse chose the arches and the courtrooms as central icons of their building.

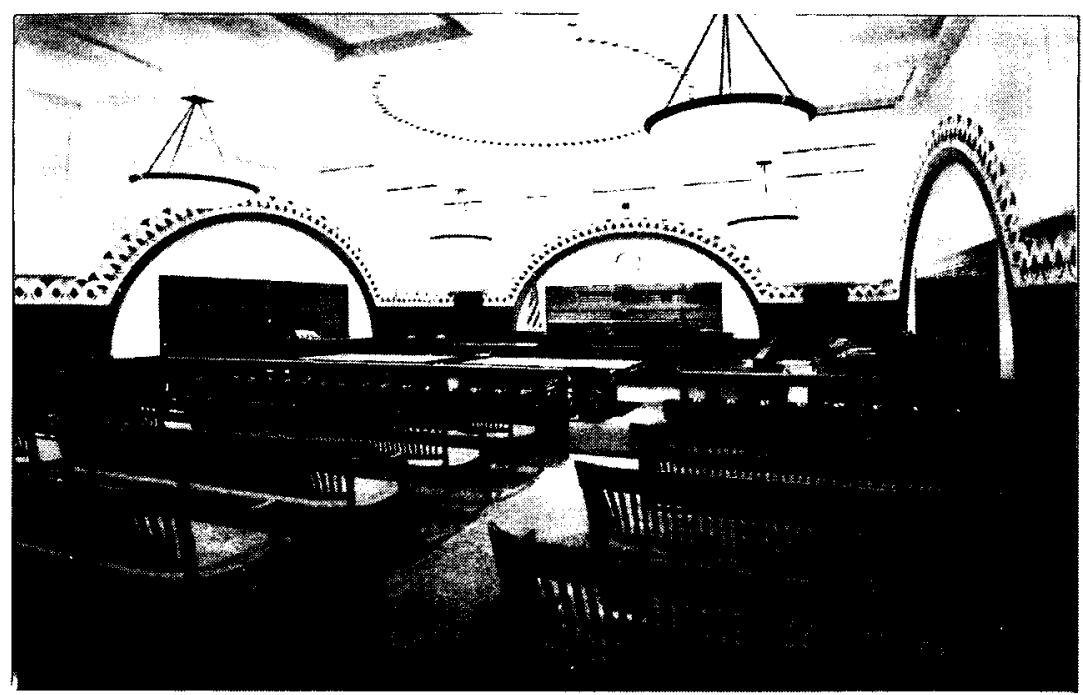

Figure 23. Interior of a courtroom, John Joseph Moakley United States Courthouse. Photograph Copyright: Steve Rosenthal, 1998

\section{Reconfiguring Rights and Processes}

But there is a disjuncture between all of the new buildings, the courtrooms, and the rules and practices enveloped in constitutional precepts and what is happening in adjudicatory processes in the United States. The job of the judge has changed, for they are now multi-taskers-sometimes managers of lawyers and of cases, sometimes mediators, sometimes referral sources sending people outside of courts to alternative fora. In the United States and elsewhere, we have seen a failing faith in adjudicatory procedure, a growth in an anti-adjudicatory rhetoric and the promotionby judges and lawyers - of alternative dispute resolution (ADR). Local rules of the Boston federal courts, for example, instruct judges to bring up the topic of settlement of cases every time that judges meet with lawyers and litigants.

Thus, concurrent with the historical narrative of the triumphant expansion of adjudication as a touchstone of thriving democracy is a competing narrative describing adjudication as in decline; with more dramatic flair, such a narrative could be claimed to represent the "death of adjudication." 60 In both public and private sectors, leaders in many countries proffer conciliation as the exemplary model of judgment. Through medi-

60. Judith Resnik, For Orwen M. Fïss: Some Reflections on the Triumph and the Death of Adjudication, 58 U. Miamı L. Rev. 173, 192-93 (2003). 
ation or negotiation, private outcomes predicated on the parties' consent are preferred to those imposed by judges through public judgment implementing state-generated regulatory norms. This worldwide movement toward ADR is propelled by political and social forces trumpeting deregulation and privatization and is staffed by lawyers and other professionals seeking and shaping new markets.

When the Boston courtroom opened in 1998, about four of 100 cases-both civil and criminal-completed trials in that district. Given twenty-five trial courtrooms available, each one was used for about seven trials per year. The opening chart (fig.1) in this Lecture makes plain that the data on trial rates in Boston are not anomalous. Moreover, the percentages have declined since the Boston Courthouse opened. Of course, trials are not the only proceeding for which courtrooms are used. But congressional investigations of the late 1990s documented that federal courtrooms were in use for proceedings about fifty-four percent of the time, and that measure included events that lasted two hours or less. ${ }^{61}$ This loss of public processes is not limited to the trial level alone. Appellate litigation is moving towards decisions "on the papers," and many of the judgments rendered thereafter are not published for use by other litigants as precedents in the cases that follow. ${ }^{62}$

But it would be an error to deduce that the evidentiary activities of adjudication have disappeared. Rather, a great many such procedures have migrated from courts to agencies, which provide another form of alternative dispute resolution. ${ }^{63}$ That development has particular relevance to the questions of public processes, public spaces, and the practices of justice.

61. See General Accounting Office, Courtroom Construction: Better Courtroom Use Data Could Enhance Facility Planning and Decisionmaking GAO/GGD97-39, at 2-3 (1997); see also General Accounting Office, Courthouse Construction: Sufficient Data and Analysis Would Help Resolve the Courtroom-Sharing Issue GAO-01-70, at 8, 18 (2000).

62. See Penelope Pether, Inequitable Injunctions: The Scandal of Private Judging in the U.S. Courts, 56 Stan. L. Rev. 1435 (2003); see also Sarah E. Ricks, A Modest Proposal for Regulating Unpublished, Non-Precedential Federal Appellate Opinions While Courts and Litigants Adapt to Federal Rule of Appellate Procedure 32.1, 9 J. App. Prac. \& ProCESs 17 (2007). On the lack of access to district court decisions, see Hillel Y. Levin, Making the Law: Unpublication in the District Courts, 53 VILL. L. Rev. 973 (2008).

63. See Judith Resnik, Migrating, Morphing and Vanishing: The Empirical and Normative Puzzles of Declining Trial Rates in Courts, $1 \mathrm{~J}$. EMPIRICAL Leg. STUd. 783 (2004). 
The growth of administrative adjudication can be seen by considering the graph (fig.24), called Authorized Judgeships in Federal Court Houses and in Federal Agencies (as of 2001). On one side is a count of judgeships authorized to work in federal courthouses; included are life-tenured judges appointed through the constitutional process specified in Article III as well as magistrate and bankruptcy judges who serve for renewable terms that are fixed through statutory provisions. About 1,650 authorized positions exist, as contrasted with some 4,700 administrative law judges or hearing officers who work in federal agencies.

\section{Authorized Judgeships in Federal Court Houses and in Federal Agencies (as of 2001)}

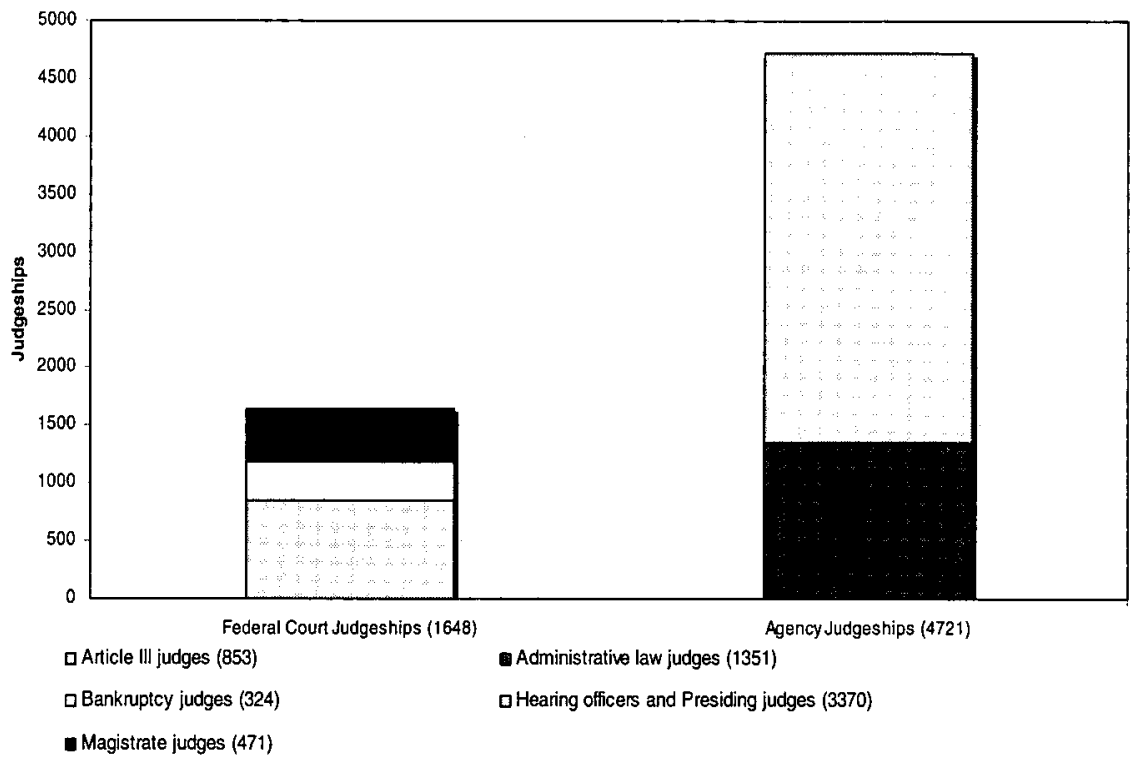

Figure 24. Copyright Judith Resnik, 2007 
Another bar graph (fig.25) provides information on all kinds of "evidentiary hearings" (not only trials) that took place in federal courthouses such as those in St. Louis (fig.21) and in Boston (fig.22). Counted on the courthouse side are the 100,000 hearings that took place before either lifetenured judges or statutorily-chartered magistrate and bankruptcy judges.

\section{Estimate of Evidentiary Hearings in Federal Courts and in Four Federal Agencies (2001)}

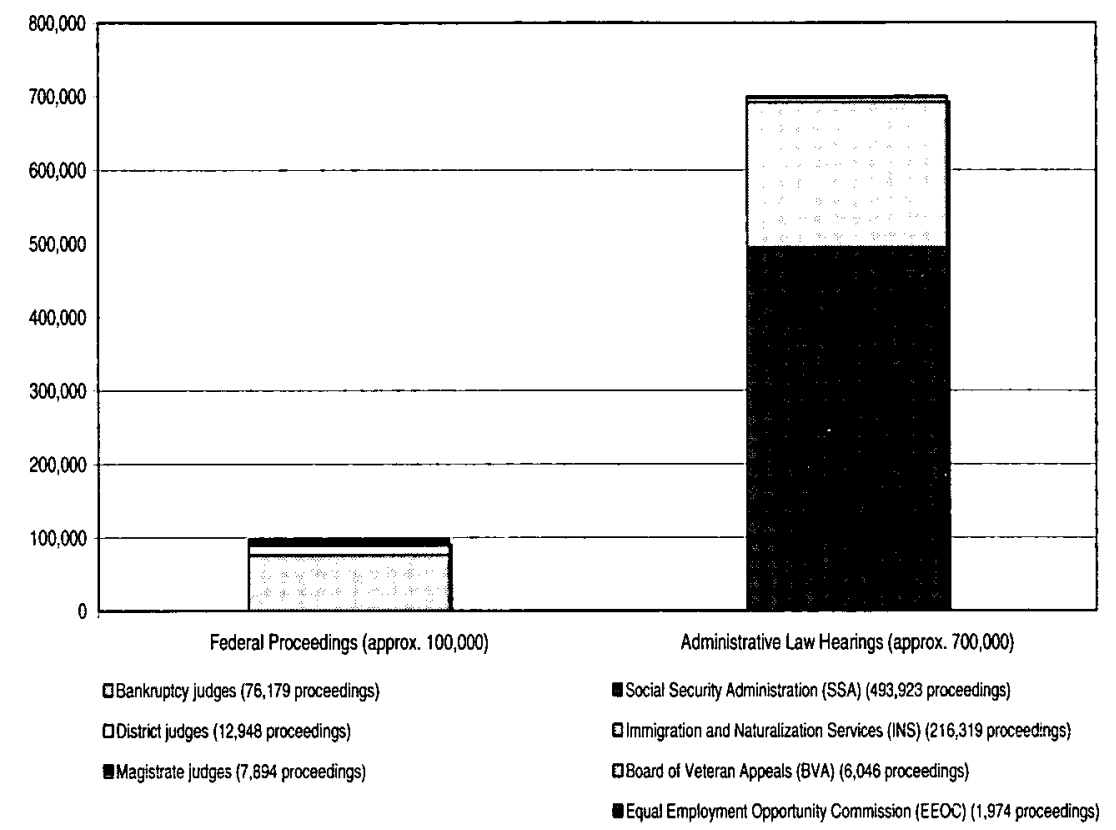

Figure 25. Copyright Judith Resnik, 2007

The other bar shows some 700,000 evidentiary hearings that occurred in four federal agencies-the Social Security Administration, the Equal Employment Opportunity Commission, the Immigration Service and the Department of Veterans' Affairs. ${ }^{64}$ Thus, although the taking of evidence in federal courts may be "vanishing," many evidentiary processes have migrated into agencies that have functionally become courts. Courts have thereby "outsourced" their products to agencies as well as to private sector providers about which too little data are available to know the volume of proceedings.

64. Thanks for help in compiling this chart are owed to Jennifer Peresie, Natalie Ram and Bertrall Ross who did so assisted by advice from administrative law experts Michael Asimow, Steven Croley, Gene Fidell, Jeffrey Lubbers, Elizabeth Magill, Jerry Mashaw, and from Yale Law School librarian Camilla Tubbs. 
Administrative adjudication takes place in federal office buildings that are multifunction spaces, as were Renaissance town halls. But unlike town halls, these office buildings are not often gracious statements of public prosperity and good governance but rather dreary settings. Further, when compared with the federal courthouse buildings, agency administration is impoverished-not only visually (in terms of the art and architecture)-but in terms of the salaries paid to the judges, the lack of lawyers for litigants, and the high volume and short duration of the proceedings.

As for public access, no ready way exists to be able to watch these exchanges in which government officials-hearing officers, administrative law judges and other agency employees-decide the rights and obligations of hundreds of thousands of persons. In terms of the governing regulatory regime, some of the administrative hearings are presumptively open (such as social security hearings) and others presumptively closed. But, as a practical matter, even if one has the "right" to attend these various proceedings, it is difficult to find them. Unlike the courthouses with designated courtrooms for public observances, the office spaces used by agencies do not invite "street traffic." And in terms of the decisions, no commercial service collects all the judgments and either publishes them in books or posts them on the internet.

Having tracked the reconfiguration of processes in court and the devolution or outsourcing of processes to agencies, one more site needs to be explored: private dispute resolution. In the United States, federal judges who had once declined to enforce ex ante agreements to arbitrate federal statutory rights generally now insist on holding parties to such bargains, thereby outsourcing an array of claims. The result can be seen in the reproduction below of my own cell phone contract (figs.26 and 27). ${ }^{65}$ The contract requires that I waive all rights to court, to class action treatment or to aggregate treatment in arbitration, and that I use a private dispute resolution procedure provided by the company. No member of the public has a right to attend nor to obtain data about outcomes, costs, and process.

65. See Verizon Wireless eStore, Your Verizon Wireless Customer Agreement, http://www.vzwshop.com/pops/customeragreement_popup.aspx (last visited June 28, 2008). Other providers have similar limitations. See, e.g., Sprint, Terms and Conditions: Terms and Conditions of Service, http://www.sprintpcs.com/ common/popups/popLegalTermsPrivacy.html\#2 (last visited June 28, 2008). On the enforcement of such provisions, see generally Caley v. Gulfstream Aerospace Corp., 428 F.3d 1359 (11th Cir. 2005). That decision enforces an arbitration clause despite arguments by employees seeking class treatment of claims under the Age Discrimination in Employment Act and the Employee Retirement Income Security Act, as well as individual claims under Fair Labor Standards Act and Title VII; and Jean R. Sternlight \& Elizabeth J. Jensen, Using Arbitration to Eliminate Consumer Class Actions: Efficient Business Practice or Unconscionable Abuse?, 67 LAw \& CoNTEMP. Probs. 75 (2004). 


\title{
Example of Celluar Phone Contract: 2002 Your Cellular Service Agreement
}

\author{
Please read carefully
}

before filing in a safe place.

\section{YOUR CELULAR SERVICE AGREEMENT}

This agreement for œllukr serviœ betwen you and [your] wireless [company] sets your and aur legal rights conœrning payments, oredirs, changes, stating and ending service, early termi ration fæs, limitatiors of liability, settement of dispuesby neutral arbitraion instead of jur y trials and dass actions, and other impotant topics. PLEASE READ THIS AGREEMENT AND YOUR PRICE RLAN. IF YOU DISAGREE WITH THEM, YOU DON'T HAVE TO ACCEPT THS AGREEMENT.

IF YOURE A NEW CUSTOMER, THIS ACREEMENT STARTS WHEN YOU OPEN THE INSIDE PACKAGE OF ANY CELL PHONE YOURECEIVED WTHTHS AGREEMENT ... . IF YOU DONT WANT TO ACCEPT AND BE BOUNDBY THIS AGREEMENT, DONT DO ANY OF THOSETHINGS. INSTEAD, RETURN ANY CELL PHONE YOURECEVED WTH THIS ACREEMENT (WITHOUT OPENING THE INSIDE PACKAGE) TO THE PLACE OF PURCHASE WITHIN 15DAYS.

IF YOU'RE AN EXISTING CUSTOMER UNDER APRIOR FORMOF AGREEMENT, YOUR ACCEPTINGTHIS AGREEMENT IS ONE OFTHE CONDITIONS FOR OUR GRANTINGYOU ANY OF THE FOLLOWNG CHANCESIN SERVICE YOU MA Y REQUEST: ANEW PRICE PLAN, A NEW PROMOTION, ADDITIONAL LINES N SERVICE, OR ANYOTHER CHANGE WE MAY DESIGNATE WHEN YOUREQUEST IT (SUCH AS A WAIVER OF CHARGES YOU OWE. . ... YOU CAN GO BACK TO YOUR OLDSERVICE UNDER YOUR PRIOR AGREEMENT AND PRICE PLAN BY CONTACTING US ANY TME BEFORE PAYING YOUR FIRST BLL AFTER WE MAKE THE CHANGE YOUREQUESTED. OTHERWSE, IF YOU PA YY YUR BILL, YOU'RE CONFRMING YOUR ACCEPTANCE OF THS AGREEMENT. IF YOU DONT WANT TO ACCEPT THIS AGREEMENT, THEN DONT MAKE SUCH ACH ANCE AND WE' $L L$ CONTINUE TO HONOR YOUROLD FORM OF AGREEMENT UNIESS OR UNTIL YOU MAKE SUCH A CHANCE. . . . 
Example of Cellular Phone Contract: 2002 (cont.)

\section{INDEPENDENT ARBITRATION}

INSTEAD OF SUNG IN OOURT, YOU'RE AGREEING TO ARBIIRATE DISPUIES ARISINGOUT OF ORRF ATEDTO THSOR FRI CR AGREEMENIS. THIS AGREEMENT INVOLVES COMMERCEAND THE FEDERAL ARBITRATION ACT APH JES TOTT. ARH TRATION ISNT THESAME AS COURT. THE RULES ARE DIFFERENT AND THRRES NO JUDCE AND JURY. YOU AND WE ARE WAIVING RIGHIS TO PA RIIOPATE IN OLASS ACTIONS, INOUDNG PUTATIVE CLASS ACTIONS BEGUNBY OTHERS FRIOR TO THSAGREEMENT, SO READ THS CARFFULYY. THS AGREEMENT AFHECTSRIGHTS YOU MIGHTOTHERWSE HAVE INSUOH ACTIONS THAT ARE OURRENTLY PENDING AGAINT US QR OURPREDECESSORSINWHICH YOU MGHT BE A POIENII AL, OLASSMEMBER (We retain our rights to complan to any reglabry agency or commission) YOU ANDWE EAOH AGREE THAT, TO THE FUL LEST EXTENTPOSSIBLE PROVIIED BY LAW:

(1) ANY CONTROVERSY ORCLAIM ARISING OUTOFOR RE_ATING TO THIS AGREEMENT, ORTO ANY RRIOR AGREMENT PORCE.LULAR SERVICE WTH US. . . WIL BE SETTLED BY INDEPENDENT ARBIRATION INVOLVING A NEUTRAL ARBITRATOR AND ADMNISTEREDBY THE AMERICAN ARBITRATION ASSOCIATION ("AAA") UNDER MRELESS INDUSTRY ARBTRATION ('WIA') RUIES, AS MODIFEDBY THISAGREEMENT. WA RULES AND FEE INFORMATION ARE AV AILABLE FROMUS OR THE AAA;

(2) EVEN IF APHLICABI ELAW FERMIIS Q AASS ACTIONS ORCLASS ARBITRATIONG, YOU WAIVEANY RIGHT TO FURSUEON ACLASS BASIS ANY SUCHCONTROVERSY OR OLAIM AGAINST US ... AND WE WAIVE ANY RIGHT TOFURSUE QN A CASS BASSANY SUCH CONIROVERSY OR OLAIMAGAINST YOU. ...

(3) No arbitrator has authority to award relief in excess of what this agreemert provides, or to order consolidation or dass abitration, except that an arbitrator deciding a daim aris ing out of $\alpha$ rdating to a pria ageament may grant a muh substantive refi of on a non-dass bas is as such prio agreenent would permit. NO MATTER WHAT ELSE THIS AGREEMENT SAYS, IT DOESNT AFFECT THESUBSTANCEOR AMOUNT OF ANY CLAIM YOU MAY ALREADY HAVE AGAINST US ORANYOFOURAFFILATES OR PREDECES SORS IN INTEREST PRDR TOTHIS AGREEMENT. THS AGREEMBNT JUST REQUIRES YOU TO ARBTRATE SUCH CLAIMSON ANINDIVIDUAL BASIS. In arbitrations, the arbitrator must give offect to applicable statutes of limitaions and will decide whether an isse is abitrableor nd. In a LargelComplex Case arbiration, the arbitrators must ako apply the Federal Rules of Evidence and the losing par ty may have the award revieued by a panel of 3 arbitrators.

(4) IF FOR SOME REASONTHESEA RBITRATION RFQUIREMENISDONT AFPLY, YOU AND WE EACH WAIVE, TOTHEFUUESTEXTENT ALLOWED BY LAW, ANY TRIAL BY JRY. A JUDCE WILLDECIDEANY DSPUIE INSTEAD;

(5) NOMATTERWHATEL SE THS AGREEMENT SAYS, ITDOESN'T APHLY TOCR AFFECT THE RIGHIS IN ACERIIFI EDCLASS ACIION OF A MEMBEROF A CERIIFIED OASS WHDFIRST REOEIVES THSAGREMENT AFTER HS QLASSHAS BEEN CERIIFED ORTHERIGHIS IN ANACTIONOF A NAMED PLAINIIF, ALTHDUGHITDOES APLYTO OTHER ACTION, CONIRONERSIES, OR OAIMSINVOLVING SUCH FERSONS.

Figures 26 and 27. Example of Cellular Phone Contract, 2002 
"Bargaining in the shadow of the law" is a phrase often invoked, but bargaining is increasingly a requirement of the law of conflict resolution. ${ }^{66}$ As a consequence, the distinctive character of adjudication as a specific kind of "social ordering" that could be contrasted with otherssuch as contracts and elections (to borrow Lon Fuller's terminology and categories ${ }^{67}$ ) -is diminishing. Through case management, judicial efforts at settlement, mandatory ADR, enforcement of ex ante waivers of rights to trial and devolution to closed agency processes, the framework of "due process procedure" is replaced by what $I$ think is fairly called "contract procedure." 68

\section{The Democracy in Adjudication}

A return is now in order to the questions I put forth at the outsetperhaps best summarized as "so what?" Many people would concur with the description that I have proffered about the changing contours of adjudication but come to the conclusion that the shifts are to be celebrated. Proponents of this view focus on how adjudication can be cumbersome and expensive, and its public dimensions burdensome and painfully invasive of privacy. They argue that reconfiguration is appropriate not only in response to demands imposed by the volume of cases, but also because other methods are better suited to solve the problems. Moreover, in a world overloaded with information and many displays of "reality" through disclosure of personal data, no need exists for more. Websites, blogs, and newspapers do more than enough to populate the public sphere with narratives and conflicting claims. One could thus use a combination of new technologies and the demand curve spurred by democratic precepts for adjudication as justifications for its devolution and privatization.

A recent essay by a thoughtful federal trial judge who has played a leadership role in the federal judiciary explains some of this point of view. As I have done, he too put the question in visual terms through asking about how "reality television" should portray a federal trial judge. In civil cases, he answered:

In an office setting without the robe, using a computer and court administrative staff to monitor the entire caseload and individual case progress; conferring with lawyers (often by telephone or videoconference) in individual cases to set dates or limits; in that same office at a computer, pouring over a particular lawsuit's

66. See Robert H. Mnookin \& Lewis Kornhauser, Bargaining in the Shadow of the Law: The Case of Divorce, 88 YALE L.J. 950, 950 (1979).

67. Lon L. Fuller, The Forms and Limits of Adjudication, 92 HARv. L. REv. 353, 363 (1978) (posthumously published essay based on materials written initially in late 1950s).

68. For further discussion, see Judith Resnik, Procedure as Contract, 80 Notre Dame L. Rev. 593 (2005); Judith Resnik, Trial as Error, Jurisdiction as Injury: Transforming the Meaning of Article III, 113 HARv. L. REv. 924 (2000). 
facts, submitted electronically as affidavits, documents, depositions, and interrogatory answers; structuring and organizing those facts, rejecting some or many of them; finally, researching the law (at the computer, not a library) and writing (at the computer) explanations of the law for parties and lawyers in light of the sorted facts. For federal civil cases, the black-robed figure up on the bench, presiding publicly over trials and instructing juries, has become an endangered species, replaced by a person in business attire at an office desk surrounded by electronic assistants. ${ }^{69}$

He further argued that, although judges' "mission to interpret and clarify laws, adjudicate and protect rights, maintain fair processes, and punish," has remained the same, "the method of carrying out that mission has changed." He said:

Law professors and judges should stop bemoaning disappearing trials. Trials have gone the way of landline telephones-useful backups, not the instruments primarily relied upon, if ever they were. Dramatists enjoy trials. District judges enjoy trials. Some lawyers enjoy trials. Except as bystanders, ordinary people and businesses don't enjoy trials, because of the unacceptable risk and expense. ${ }^{70}$

His position brings me to the third aspect of this Lecture, which is to sketch the contours of a normative theory from democratic practices about what is lost-and hence to be "bemoaned"-by the decline in public processes for dispute resolution. Jeremy Bentham made claims that public processes are useful in generating more accurate outcomes, and he also posited that publicity helped to produce legitimacy. I take a somewhat different tack, in that my argument is not focused on the relationship between openness and truth but instead on how public processes of courts contribute to the functioning of democracies and give meaning to democratic precepts that locate sovereignty in the people, constrain government actors, and insist on the equality of treatment under law.

Consider first the interaction between observers and courts. Public processes and published opinions permit individuals who are neither em-

69. D. Brock Hornby, The Business of the US District Courts, 10 GREEN BAG 2D 453, 462 (2007).

70. Id. at 468. Judge Hornby continued:

In the twenty-first century, the federal district courts' primary roles in civil cases have become law exposition, fact sorting, and case managementoffice tasks-not umpiring trials. In criminal cases, the judges' work remains courtroom-centered but, instead of trials, it has become law elaboration and fact finding at sentencing, supervising federal offenders after prison, and safeguarding the integrity of a criminal process that sends defendants to prison without trial. In 2007, that is the federal district courts' business. Trials as we know them, and unfettered sentencing discretion, are not coming back.

Id. at 468 . 
ployees of the courts nor disputants to learn, first-hand, about processes and outcomes. Indeed, courts-and the discussions that their processes produce-are one avenue through which private persons come together to form a "public,"71 an identity as participants acting within a political and social order. Courts make this contribution by being what could be called "non-denominational" or non-partisan, in that they are one of relatively few communal spaces open to participants whatever their other political, religious, or social affiliations. Open court proceedings enable people to watch, debate, develop, contest, and materialize the exercise of both public and private power.

Moreover, courts provide a unique service in that they create distinctive opportunities to gain knowledge. Extraordinary conflicts have many routes into the public sphere. The media (including bloggers) or members of government may initiate investigations. Courts may help uncover relevant information in these arenas (as we have seen in the litigation related to individuals detained after $9 / 11$ ), but courts distinguish themselves from either the media or other government-based investigatory mechanisms in an important respect-the attention paid to ordinary disputes. Courts do not rely on national traumas or scandals or on ad hoc enabling acts, nor on selling copies of their decisions. Further, courts do not respond only when something "interesting" is at issue.

What is the utility of having a window into the mundane? That is where people live and that is where state control can be both useful and yet overreaching. The dense and tedious repetition of ordinary exchanges is where one finds the enormity of the power of both bureaucratic states and private sector actors, and that authority is at risk of operating unseen.

By observing the redundancy of various claims of right and the processes, allegations, and behaviors that become the predicates to judgments, debate can occur not only about the particulars of a given procedure and its outcome but also about what the underlying norms ought to be. So called "domestic violence" provides one ready example of the role of public processes in reorienting an understanding of so-called private life.

The results of public knowledge gathered from open dispute resolution ought not, however, be presumed to be generative in any one direction. Public awareness can give new rights or new limits (fueling, for an example, caps on tort remedies because of visions of juries run amok). Moreover, because even a few cases can make a certain problem vivid, social policies may be forged that respond in extravagant ways to harms that are less pervasive than perceived. Criminal sanctions are exemplary here, as public disclosures of particular crimes produce anger and vengeful consequences.

71. See generally Craig Calhoun, Introduction in HABERMAS AND THE PUBLIC SPHERE, supra note 31 , at 1 . 
Publicity itself has come back into vogue as a form of punishment. Press coverage of individuals found to have sexually assaulted children prompted new laws that require individuals who are convicted of a wide array of offenses to register with government officials and to have their photos placed on the web so that, upon completion of prison sentences, potential neighbors could be forewarned about their presence. ${ }^{72}$ In short, public display does not necessarily trigger reasoned discourses. But what the publicity does enable is the ability of Foucault's "unruly crowd" to respond in ways uncontrollable by those protective of their own powers and prerogatives. ${ }^{73}$ Discipline and control of those powers may (not will, but may) follow.

Openness also changes the power relationships between the participants and their audience by undermining the ability of the government or the disputants to control the social meaning of conflicts and their resolutions. An example comes from the broadcast of the video of the death of Saddam Hussein. Recall that, on December 30, 2006, Saddam Hussein was hanged-five days after he had lost an appeal of his sentence. ${ }^{74}$

At first, the media reported that "14 Iraqi officials attended the hanging" at an unspecified location and that "witnesses said Mr. Hussein was carrying a Koran and was compliant as the noose was draped around his neck." ${ }^{75}$ But within a day, a "new video ... appeared on the Internet . . . apparently made by a witness with a camera cellphone"; that tape showed the "unruly, mocking atmosphere in the execution chamber" and recorded the taunts hurled at Hussein at his death. ${ }^{76}$ Although the organized media in different countries debated whether to air that video, the media did not control the channels of distribution, and the disclosures resulted in a torrent of reaction to and comment about the timing, fact and process of the execution. ${ }^{77}$

The uncontrollability of the distribution of that video has its counterpart in thousands of ordinary actions that take place in low level tribunals. Once events are accessible to an audience of third parties who are not

72. See, e.g., Conn. Dep't of Pub. Safety v. Doe, 538 U.S. 1 (2003) (upholding constitutionality of state laws requiring such registration and publication).

73. As Foucault detailed, government literally lost control in that, at times, the public processes of executions were sites in which crowds turned into mobs that were animated by protests about either the verdicts or the punishments. See FOUCAULT, supra note 33, at 59.

74. During the course of the trial, three defense lawyers were killed and two judges were dismissed. See John F. Burns, James Glanz, Sabrina Travernise \& Marc Santora, In Days Before Hanging, A Push for Revenge and a Push Back from the U.S., N.Y. Times, Jan. 7, 2007, at A12.

75. Marc Santora, James Glanz \& Sabrina Travernise, Saddam Hussein Hanged in Baghdad; Swift End to Drama; Troops on Alert, N.Y. Times, Dec. 30, 2006, at A1.

76. John F. Burns \& Marc Santora, U.S. Questioned Iraq on the Rush to Hang Hussein, N.Y. Times, Jan. 1, 2007, at A1.

77. Bill Carter, Graphic Video of Execution Presents Hard Choices for U.S. Media, N.Y. Times, Jan. 1, 2007, at A7 (noting that Fox News and CNN both ran video, and that Fox had followed Al Jazeera in doing so). 
themselves disputants, "spectators and auditors" (to borrow Bentham's categories $^{78}$ ) can put their descriptions and commentary into the public realm. These exchanges are rich, albeit sometimes pain-filled, sources of communicative possibilities. They empower diverse speakers, some of whom may respond by seeking vengeance and others by offering reasoned discourses, but all of whom understand themselves as having authority to speak as a consequence of what they have witnessed or read. In contrast, without direct access, non-parties must rely on insiders to reveal events, inevitably translated through their perspectives. Thus, public procedures themselves teach that conflicts do not belong exclusively to the disputants or to the government and give the public a place through which to interpret, own, or disown what has occurred.

That courts can-as an empirical matter-affect and sometimes generate public agendas addressing the intersections of private interests and public rights provides one justification for open processes that welcome an audience. In this respect, courts are one part of what many theorists call the "public sphere," and which Nancy Fraser points out ought to be understood in the plural as public spheres, rather than modeled as a unified body. ${ }^{79}$ Courts therefore contribute to the political discourses outside of their own buildings and often times beyond the parameters of particular legal or factual disputes.

But that contribution may not be sufficient to support a commitment to courts in the future. We live in the world of blogs, the internet, the organized press, and reality TV, as well as the broadcasts of legislative hearings. Places other than courts therefore offer venues that can spark debate, although, as I noted, courts are special contributors by attending to a volume of mundane matters. An additional and distinct facet of what makes courts especially useful in democracies can be seen by shifting attention from what potential spectators can see and hear to what litigants, judges, witnesses, or jurors $d o$ as participants in public dispute resolution processes.

This aspect of my argument for protection of transparent adjudication hinges on the view that adjudication is itself a democratic practicean odd moment in which individuals can oblige others to treat them as equals as they argue-in public-about alleged misbehavior and wrongdoing. Litigation forces dialogue upon the unwilling (including the government), and momentarily alters configurations of authority. The social practices, the etiquette and a myriad of legal rules shape what those who enter courts are empowered to do. ${ }^{80}$

78. Bentham, supra note 29 , at 356 .

79. Nancy Fraser, Rethinking the Public Sphere: A Contribution to the Critique of Actually Existing Democracy, in Habermas and the Public Sphere, supra note 31, at 109.

80. This understanding of law as a social practice can be seen in the work of Robert M. Cover. See Robert M. Cover, 1982 Term-Foreword: Nomos and Narrative, 
When cases proceed in public, courts institutionalize democracy's claim to impose constraints on state power. In open courts, those government employees we call judges have to account for their own authority by letting others know how and why power is used. Bentham's widely-quoted phrase captures this activity: "Publicity is the very soul of justice . . . It keeps the judge himself, while trying, under trial." 81 Such visibility-potentially a constraining power-is not available when judges sit in their offices and operate by discussions with parties on telephones or through computers. Moreover, when government officials are parties to litigation, they are subjected to scrutiny and forced either as plaintiffs or defendants to comply with court rules. Government litigants must bear the exposure that obligations of discovery impose, thereby exposing their past deeds, their files and their emails.

Courts can be great levelers in another respect, in that participatory parity is an express goal of courts, even if not always achieved. ${ }^{82}$ Litigants are supposed to interact with each other as equals, with rights to make demands on each other and to be treated as equals by judges, juries, lawyers, and staff. When courts fail to do so-in public - they serve as a place in which to expose the absence of equal treatment.

For example, during the 1970s and 1980s, as women and men of color brought claims of discrimination to courts in the United States, they found that some judges responded that differential treatment was natural. Some litigants found themselves subjected by opposing lawyers or by judges to discriminatory treatment and stereotyping. In response to such concerns, the chief justices of many state courts convened special projects, denominated "fairness" or "gender bias" and "racial bias" task forces. These projects identified areas of law (such as sentencing decisions and violence against women) in which doctrines and practices did not accord equal treatment. ${ }^{83}$ Statutes, rulemaking, and case law resulted because materials that were accessible to public scrutiny showed behaviors at odds with the provision of "equal justice under law." 84

The function of courts as potentially egalitarian political venues can be seen in the efforts to avoid them. After $9 / 11$, the Executive branch of the United States repeatedly sought to enact legislation "stripping" courts of jurisdiction over claims that the government had wrongly detained and

97 Harv. L. Rev. 4 (1983); Judith Resnik, Living Their Legal Commitments: Paideic Communities, Courts, and Robert Cover, 17 Yale J.L. \& Human. 17 (2005).

81. Bentham, supra note 29, at 355; see also Neil Andrews, English Civil Procedure: Fundamentals of the New Civil Justice System 79 (2003).

82. Fraser, supra note 79 (arguing that such parity is requisite to proper functioning of Habermasian public spheres).

83. See, e.g., Judith Resnik, Asking Questions about Gender in Courts, 21 Signs: J. WOMEn Culture \& Soc'y 952 (1996).

84. These are the words inscribed on the front of the facade of the Supreme Court of the United States. 
tortured individuals. ${ }^{85}$ The effort to create a separate "tribunal system" for alleged enemy combatants is aimed at controlling access and information as well as limiting the rights of detainees by augmenting the powers of the state.

The behavior within courts and the rights that exist inside courts are central to my argument that courts serve themselves as a site of democratic valorization of individual dignity, thereby rendering instruction on the values of a polity or insight into its inability to materialize those commitments. Moreover, in addition to undermining the state's monopoly on power, forging community ownership of norms, demonstrating inter-litigant obligations, and equalizing the field of exchange, open courts can express another of democracy's promises-that rules can change because of popular input. The public and the immediate participants see that law varies by contexts, decision-makers, litigants, and facts, and they gain a chance to argue that the governing rules or their applications are wrong. Through democratic iterations, norms are reconfigured.

To appreciate the political and social utilities of the public dimensions of adjudication is not, however, to ignore the costs and burdens imposed. (Bentham listed many. ${ }^{86}$ ) The immediate participants in a dispute may find the exposure to the public disquieting. Even the disclosure of accurate information can be uncomfortable. Further, the public dimensions of adjudication may inhibit parties' abilities to find common ground, thereby deepening discord. And, despite Bentham's confidence that public disclosure reveals falsehoods, many a court record is subsequently impeached as predicated on witnesses who lied.

Further, one should not romanticize spectatorship. Locating judgment in courthouses with windows to the streets and open doors makes publicity possible, but even then a question remains about how to secure an audience and have its members be engaged. ${ }^{87}$ Watching state-authorized processes may prompt celebration, action, or dialectic exchanges that develop new norms, but boredom can also result. Were every door to every one of the tens of thousands of administrative hearings to be open, one would not expect many (any?) to volunteer to see many of the pro-

85. See Military Commissions Act of 2006, Pub. L. No. 109-366, 120 Stat. 2600 (to be codified at scattered sections of 10,18 , and 28 U.S.C.).

86. While providing many explanations of the utility of public processes, Bentham also argued the costs of public disclosure as he analyzed justifications for privacy (such as protecting participants from "annoyance," avoiding unnecessary harm to individuals through "disclosure of facts prejudicial to their honour" or about their "pecuniary circumstances," and preserving "public decency" and state secrets). His view was that a presumption in favor of public trials should, upon occasion, give way. See Bentham, supra note 29, at 360 .

87. Bentham considered whether to have public authorities require attendance as a matter of duty or to provide compensation for attendance or to devise some other "factitious means." He also advocated that permission liberally be granted for the publication of information obtained-and for its republication. Id. 
ceedings. But it is the happenstance of observation that is the font of what makes open courts an important facet of a functioning democracy.

\section{NeIther Rites NOR Rights}

This mapping of the declining public dimensions of conflict resolution is aimed at undermining the assumption that public access to and transparent proceedings within courts is an enduring feature of courts. Procedures, laws, and norms have great plasticity. Practices that seemed unimaginable only decades ago (from the mundane examples of the relatively new reliance on court-based settlement programs to the stunning assertions by the U.S. government of the legitimacy of according little or no procedural rights to individuals at Guantánamo Bay and elsewhere) are now parts of our collective landscape.

But neither ought one assume that secrecy is an essential characteristic of the alternatives (agencies, ADR, private providers) to courts. As the variety of rules and customs surrounding court-annexed arbitration suggests, even as judges and other dispute resolution providers move away from trials and focus on pretrial management and dispute resolution in chambers and conference rooms, it is possible to build in a place for the public ("sunshine," to borrow the term that legislators have used) or to wall off proceedings from the public.

For example, at the UCLA conference on transparency, Professor Stephen Yeazell proposed a database of civil settlements to provide a market of information about such agreements. He noted that a software program-aptly named Colosses-exists that could make that proposal practical, were there political will and financial support as well as protections for privacy. ${ }^{88}$ His proposal underscores that whatever the places constituted as authoritative, opportunities exist to engender or to preclude communal exchanges. ${ }^{89}$

As Jeremy Bentham explained, it was possible for "publicity" to occur through "natural" instruments- "without any act done by any person (at least by any person in authority) with the intention and for the purpose of producing or contributing to the production of this effect." ${ }^{90}$ Alternatively, the ability to have decision-making in public came from what Bentham termed "factitious" opportunities, which were those "brought into existence or put in action by the hand of power." ${ }^{11}$ The creation of buildings-of courtrooms as sites of adjudication-with doors thus required that one had to decide whether to make them public or not. As Bentham said,

88. See Stephen C. Yeazell, Transparency for Civil Settlements: NASDAQ for Lawsuits?, RAND \& UCLA Sch. of Law Conference, Transparency in the Civil Justice System (Nov. 2, 2007) (on file with author).

89. BenTHAM, supra note 29 , at 354.

90. Id.

91. Id. 
Considered in itself, a room allotted to the reception of the evidence in question . . . is an instrument rather of privacy than of publicity; since, if performed in the open air . . the number of persons capable of taking cognizance of it would bear no fixed limits . . . .92

Bentham's imagery and terminology helps us all to see that the question of public or private proceedings entails political choices. To create a public space as an active site requires normative commitments, predicated on a political theory about the role that the audience plays in juridical proceedings. This excursion into a mélange of cultural history, custom, practice, data, and rules is aimed at provoking efforts to generate such theories. I hope to have undermined some of the presumed stability that could come from a first reading of the Sixth Amendment of the United States Constitution, from Article 6 of the European Convention on Human Rights, or from viewing the thousands of impressive courthouses in countries around the world.

Having mapped some of democracy's debts to adjudication and in turn, the challenges that democracy has now posed for adjudication, one can see that the question of "transparency" is not only in play when cases are seen as raising problems for "national security." The display of justice is on the wane in some of the venues in which it was once vibrant, and its relocation to other locations has not been accompanied by either rites or rights of audience. As the processes of judgment become increasingly rare, they return to the realm of the spectacle, the audience becomes voyeuristic rather than democratic and power flows back to the producers.

92. Id. 